\author{
Income Inequality and Political \\ Polarization: Time Series Evidence \\ Over Nine Decades \\ John V. Duca and J ason L. Saving \\ Federal Reserve Bank of Da llas \\ Research Department \\ Working Paper 1408
}




\title{
Income Inequality and Political Polarization: Time Series Evidence Over Nine Decades
}

\author{
John V. Duca, Federal Reserve Bank of Dallas, (john.v.duca@dal.frb.org) \\ and Southern Methodist University, Dallas \\ Jason L. Saving, Federal Reserve Bank of Dallas, (jason.saving@dal.frb.org) \\ Research Department, P.O. Box 655906-5906, Dallas, TX 75265
}

January 2014

\begin{abstract}
$\underline{\text { Abstract }}$
Rising income inequality and political polarization have led some to hypothesize that the two are causally linked. Properly interpreting such correlations is complicated by the multiple factors that drive each of these phenomena, potential feedbacks between inequality and polarization, measurement issues, and statistical challenges for modeling non-stationary variables. We find that a more precise measure of inequality (the inverted Pareto-Lorenz coefficient) is statistically related to polarization while a less precise one (top 1\% income share) is not, and that there are bi-directional feedbacks between polarization and inequality. Findings support a nuanced view of the links between polarization and inequality.
\end{abstract}

JEL Codes: D72, D63, D31

Keywords: political polarization, inequality

* We thank Michael Weiss and seminar participants at Johns Hopkins for comments and suggestions. The views expressed are those of the authors and do not necessarily reflect those of the Federal Reserve Bank of Dallas or the Federal Reserve System. Our study analyzes shifting political trends and in no way should be interpreted as endorsing or criticizing any political party or figure. Any errors are ours alone. 
Income inequality and political polarization have risen in the U.S., as illustrated in Figure 1 and documented by a host of inequality studies (Atkinson, Piketty, and Saez, 2011, inter alia) and tracked by Poole and Rosenthal's $(1997,2007)$ index of polarization in the U.S. Congress and the partisan thermometer ratings from the American National Election Studies (Prior, 2007). The coincidence of and controversy about these trends has led some to hypothesize that increased inequality and political polarization are linked, such as Feddersen and Gul (2013), Poole, Rosenthal, and McCarty (2002, 2006, forthcoming) and Stiglitz (2012). Understanding the factors that shape, and are shaped by, greater polarization can be important for assessing the macro-economic and political-economic prospects for the U.S. and possibly other countries as well. Indeed, the economic repercussions of increased polarization in Congress was evident in the 2011 political impasse over the Treasury's debt ceiling, which raised fears that the U.S. might default and prompted Standard \& Poor's (2011) to downgrade the credit rating of Treasury debt in September 2011.

While some political science researchers have studied polarization, most of their evidence relies on cross sectional patterns, which limits our ability to understand the key factors that may have shifted polarization and income inequality over time. As a result, analyzing time series trends may be helpful. So far, studies have mentioned correlations between income inequality and political polarization, but interpreting correlations is challenged by the multiple factors that drive each of these developments, potential feedbacks between inequality and polarization, and statistical challenges for modeling non-stationary variables. In short, it is sometimes difficult to determine what is driving what and why.

In a related study, Duca and Saving (2012a) found that media fragmentation had a stronger statistical association with polarization than did income inequality. ${ }^{2}$ Furthermore, there are different potential channels for how inequality may induce greater polarization, as well as

\footnotetext{
${ }^{1}$ For more on polarization and macroeconomic implications, see Mian, Sufi, and Trebbi (2012).

${ }^{2}$ For more on the effects of the rise of cable TV, see Baum and Kernell (1999) and Prior (2007).
} 
different measures of inequality. Duca and Saving (2012a) also found suggestive evidence that, when one goes beyond simple income shares as a measure of inequality, a more complicated statistical relationship between inequality and polarization emerges. This post-WWII finding is reflected when comparing Figure 1, which along with polarization plots biennial averages of the income share of the top 1 percent of families, with Figure 2, which charts a more accurate gauge of income inequality, the inverted Pareto-Lorenz coefficient which measures income inequality within the top 10 percent of families. Juxtaposing Figures 1 and 2 suggests appears that the more accurate measure of inequality (the inverted Pareto-Lorenz coefficient) is more consistently correlated with polarization indexes than the income share of the top 1 percent.

Duca and Saving (2012a) also found post-WWII evidence of bi-directional feedbacks between a precise measure of inequality (the Gini coefficient) and polarization, ostensibly reflecting the impacts of inequality on polarization and how shifts in federal policies may affect

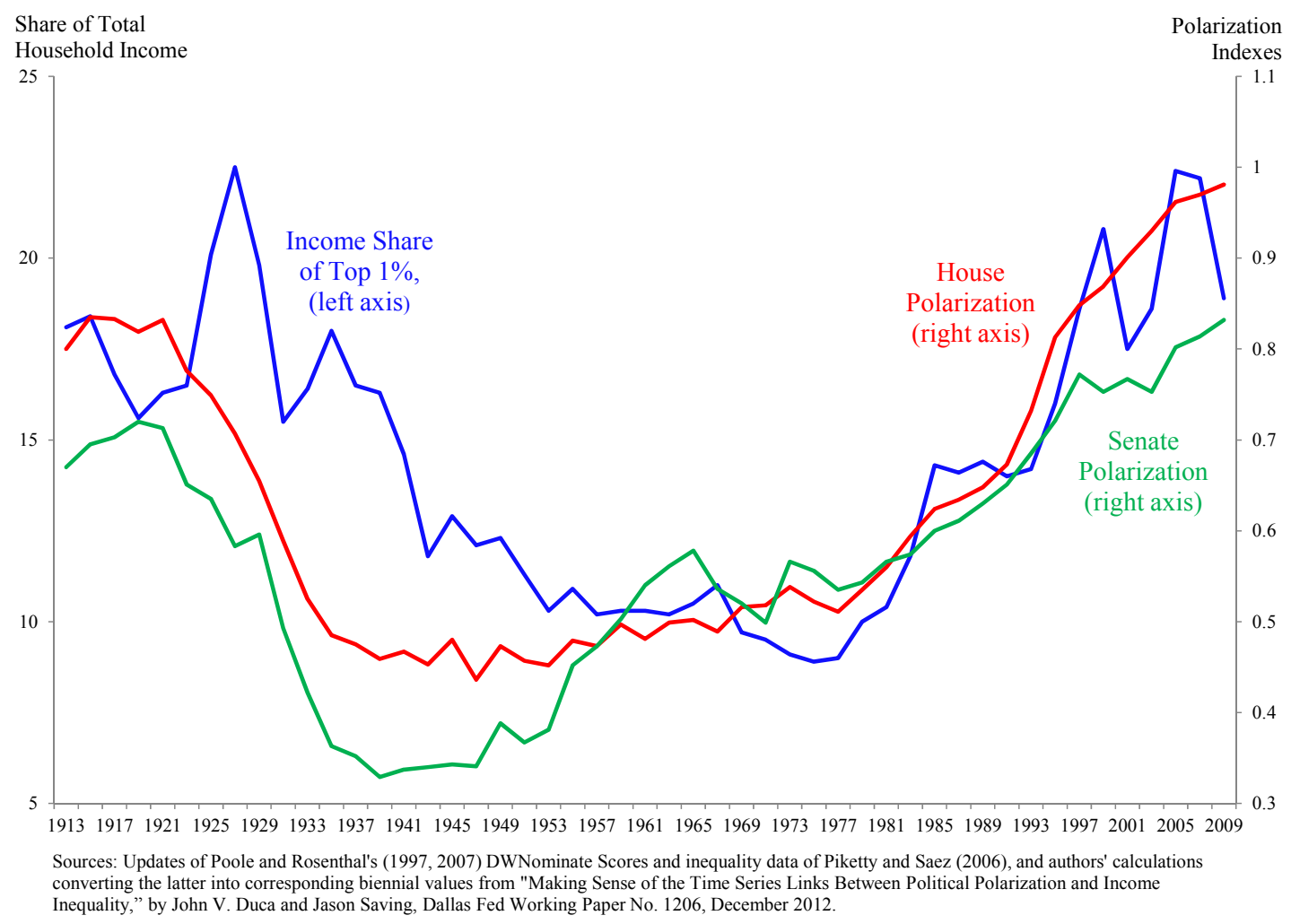

Figure 1: Political Polarization and the Income Share of the Top 1\% 


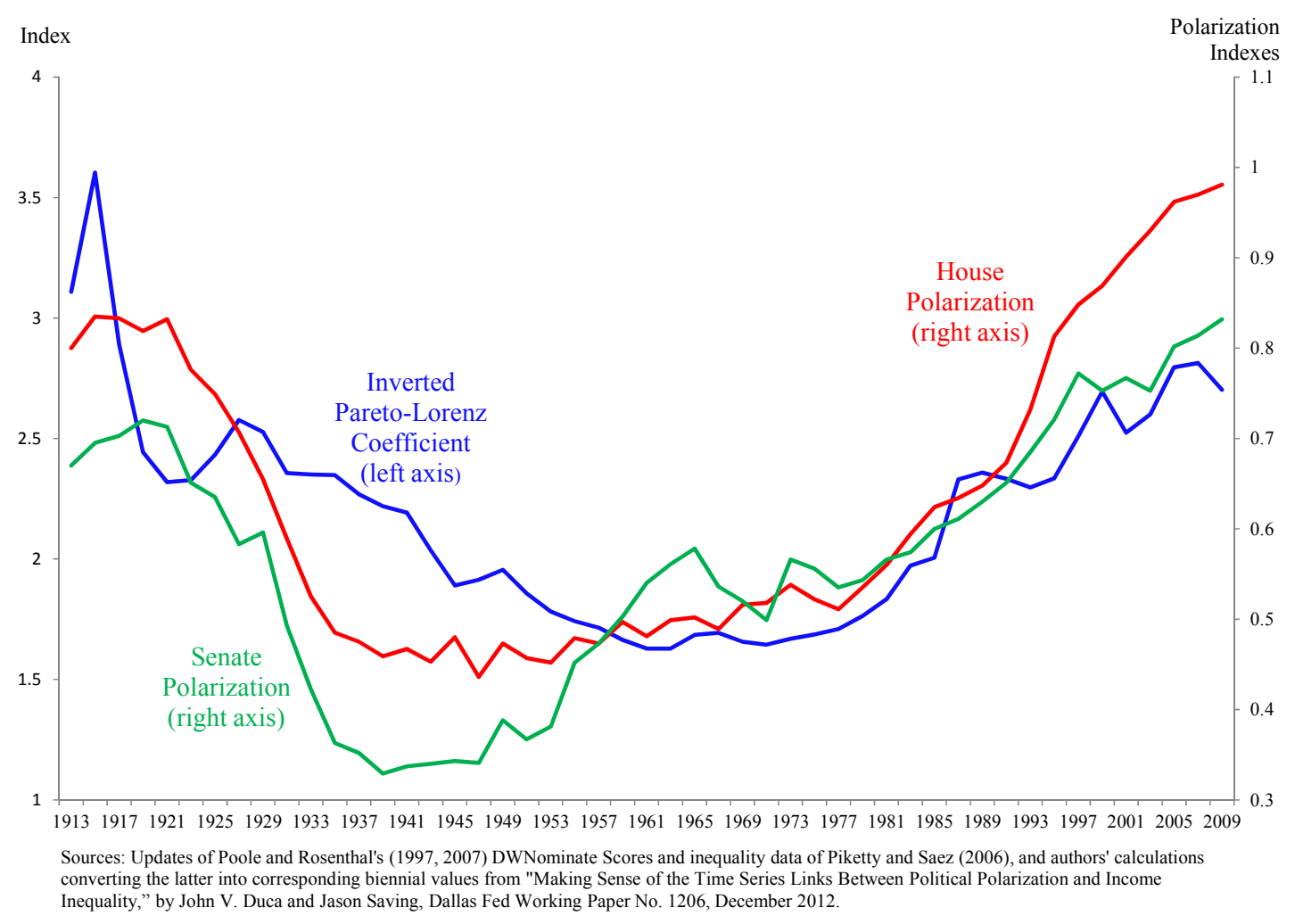

Figure 2: Political Polarization and A Broad Measure of Income Inequality

inequality (e.g., the New Deal up until the Reagan revolution of the 1980s). In Figure 2, it appears that Senate polarization falls ahead of the broad inequality measure in the 1930s, while the latter rises slightly ahead of polarization since the early 1980s. Owing to the use of data on TV ownership as a proxy for media fragmentation, the Duca and Saving (2012a) study only covers a post-WWII sample, a limitation that makes it difficult to interpret the few low frequency trends in polarization, which fell in the 1930s, stayed low until the 1970s, and recently returned to pre-Depression era levels (Poole, Rosenthal, and McCarty, forthcoming). The current study analyzes time series data starting in 1913, when income statistics began with the start of a federal income tax, and carefully distinguishes between various measures of income inequality potentially relevant to the polarization debate. Results confirm a more nuanced view of the links between polarization and inequality.

To present these findings, Section 2 briefly reviews the measures of income inequality and the factors influencing inequality, and then measures of political polarization and possible 
influences affecting it. Section 3 then reviews possible interactions between the two types of data, as well as testable hypotheses. The fourth section then presents and reviews the time series evidence on the statistical relationship between income inequality and political polarization. The conclusion provides some interpretation and perspective on the empirical results.

\section{Possible Factors Influencing Income Inequality and Political Polarization}

This section briefly reviews the empirical measures of income inequality and political polarization, and then discusses how are each influenced and driven by a variety of possible factors. Their endogenous response to outside influences has implications for both analyzing their time series relationship with each other and interpreting the time series results.

\section{IIA. Measuring Income Inequality Over the Past 100 Years}

In this study, we use two measures of income inequality: from Piketty and Saez (2006): the income share of the top 1 percent of families $(\text { Top } 1 \%)^{3}$ and the inverted Pareto-Lorenz coefficient (IPL, a term coined by Atkinson, 2003). The latter can be interpreted as a more precise measure of income inequality. As Atkinson, et al. (2011) point out, the information content of arbitrary income shares is subject to temporary income shocks and distortions that can be affected by the particular, arbitrary choice of a threshold level of income. As a result, the inverted Pareto-Lorenz coefficient is less noisy than the top 1 percent income share (Figure 3).

In contrast, the inverted Pareto-Lorenz coefficient, which measures the degree of inequality within an income range (for example, the top $10 \%$ as in Piketty and Saez, 2006), is much less distorted by the choice of a threshold level of income. ${ }^{4}$ The specific inverted ParetoLorenz coefficient used here describes how unequal the share of income is within the top $10 \%$ of

\footnotetext{
${ }^{3}$ Since Senate polarization is more strongly correlated with the share of income inclusive rather than exclusive of capital gains (.52 versus .42), in line with Duca and Saving's (2012a) post WWII results, the two inequality variables used are based on income including capital gains, which outperformed the top 1\% share omitting gains. ${ }^{4}$ Using measurements based on the Pareto distribution benefits from that distribution's property that the ratio of average income of those with incomes above a threshold $y^{h}$ to the threshold level $y^{h}$ does not depend on $y^{h}$. This ratio, $\beta$, equals $\alpha /(\alpha-1)$, where $\alpha$ is a coefficient describing the cumulative distribution of income (y) used by Pareto: $1-\mathrm{F}(y)=(k / y)^{\alpha} \quad(k>0, \alpha>1)$, with a corresponding density of income function $\mathrm{f}(y)=\alpha k^{\alpha} / y^{(1-\alpha)}$. A lower level of $\alpha$ implies a more unequal distribution of income, and implies a higher level of $\beta$.
} 
the income distribution. The inverted Pareto-Lorenz coefficient, which Piketty and Saez (2006) measure based on income tax returns, moves closely with the Gini coefficient (Figure 4) in the post-WWII era. We use the inverted Pareto-Lorenz coefficient as our measure of income inequality because before WWII, the U.S. income tax was levied at high income levels for which there is more consistent reporting of family income. This allows the inverted Pareto-Lorenz coefficient for the upper $10 \%$ of incomes to be estimated more directly than Gini coefficients in the pre-WWII era.

\section{IIB. Measuring Political Polarization Over the Past 100 Years}

The two measures of political polarization we consider are the Poole and Rosenthal $(1997,2007)$ indexes of polarization in the House and Senate (PolarH and PolarS, respectively). Unlike interest-group measures that consider only certain votes and are often geared toward finding certain results, the DW-Nominate scores from Poole and Rosenthal consider all votes

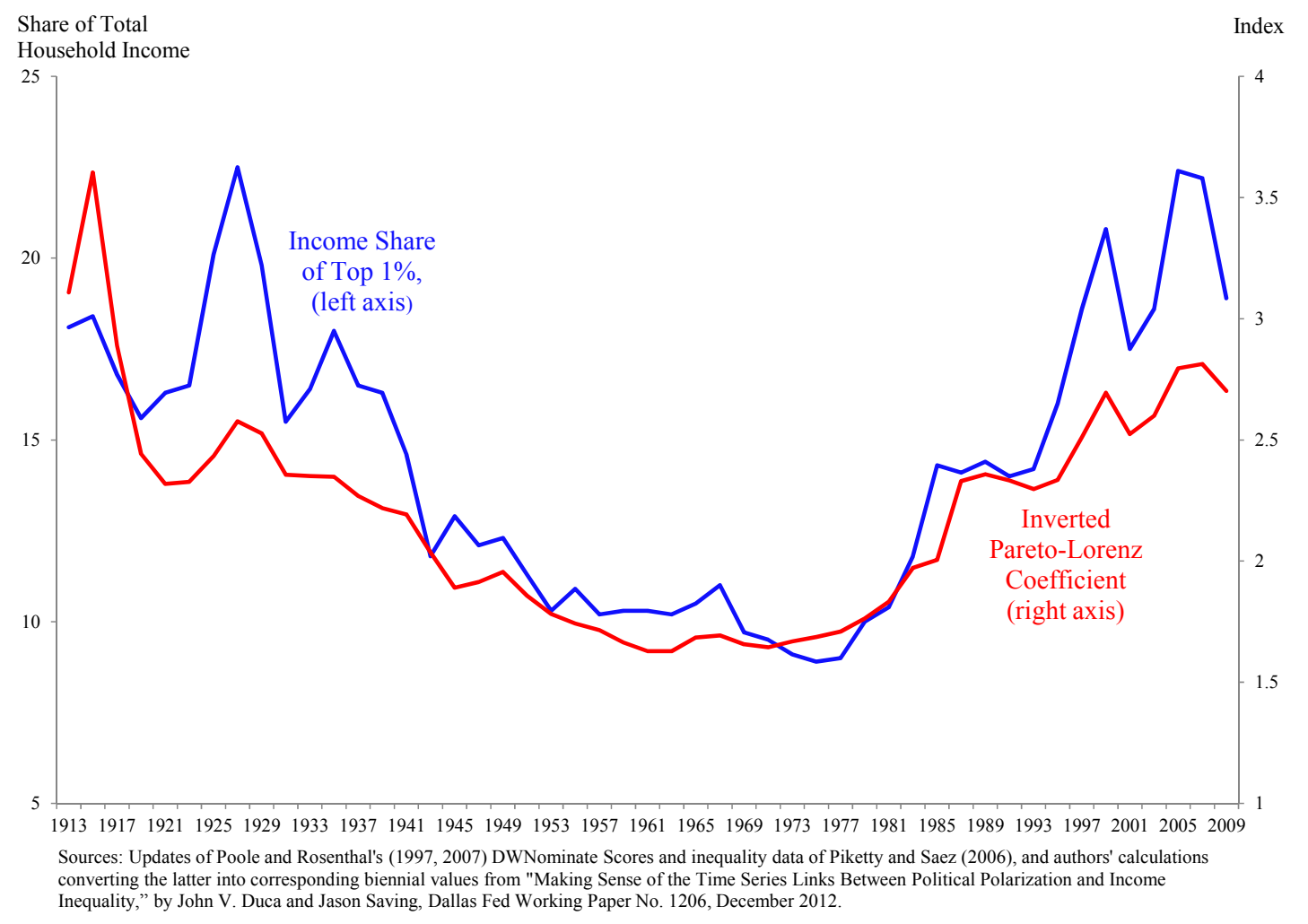




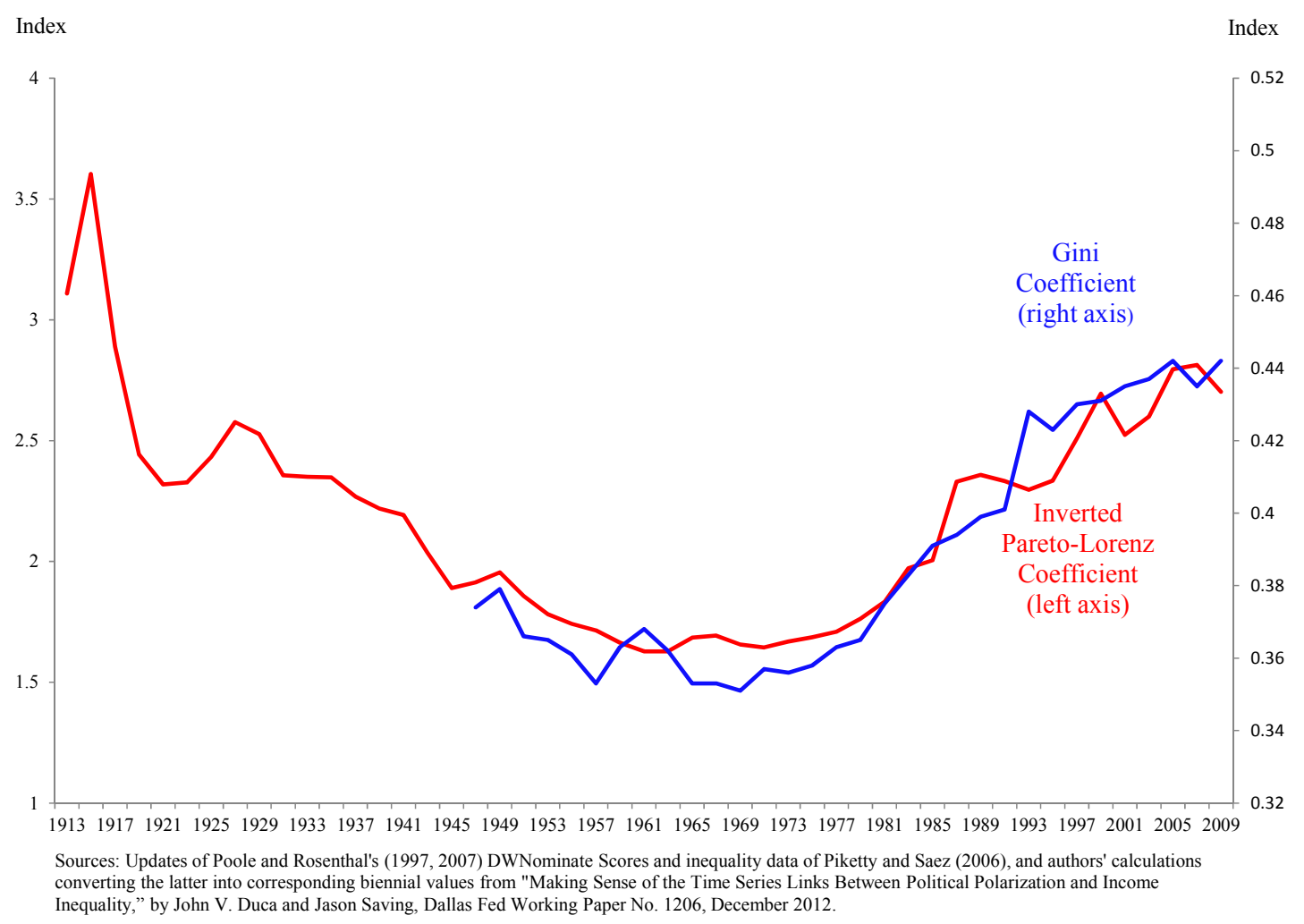

Figure 4: Post-WWII Gini and Inverted Pareto-Lorenz Coefficients Are Highly Correlated

without regard to partisan considerations. The polarization index for each is based on estimates of legislator ideal points from a spatial representation or mapping of legislator preferences along a scale between -1 and 1 , where it is assumed that legislators' votes reflect their underlying preferences with some allowance for individual preferences to evolve. Using different criteria, one can construct an ideal point for legislators from each of the parties, and then calculate how much the average position of Democratic and Republican legislators has diverged at different points in time. ${ }^{5}$ This polarization index tracks the ordinal or relative (not cardinal or absolute) preferences of the parties over time. We use the polarization indexes based on the primary dimension of differences that Poole and Rosenthal track, which they argue corresponds to the role of the government in the economy in the modern sense of the terms liberal-moderateconservative.

\footnotetext{
${ }^{5}$ For a nontechnical description of the Poole and Rosenthal methodology, see McCarty (2010).
} 


\section{IIC. What Influences Income Inequality and Political Polarization?}

Increased inequality and political polarization have been linked to several sources in the empirical literature, depicted by the upper most and lower most boxes of the flow chart in Figure 5. Changes in technology, depicted by the left-most middle-box, have generally reduced the returns to less-skilled labor raising the skill/education premium and contributing to increased inequality (see Atkinson, et al., 2011 Goldin and Katz, 2007, and Lemieux, 2006, inter alia). Technological changes, particularly since the 1970s, have also contributed to a fragmentation of visual media linked to the rise of cable TV (Baum and Kernel, 1999, and Duca and Saving, 2012a,b). This may contribute to increased political polarization, depicted in the lowest box of Figure 5, either through the effect of reducing the watching of news via providing more nonnews entertainment alternatives (Prior, 2005, 2007) or through a "silo" effect of TV viewers selfsorting into watching news from biased sources that reinforce viewer priors (e.g., Campante and Hojman, 2010; Gul and Pesendorfer, 2012; Iyengar and Hahn, 2009; and Sunstein, 2007).

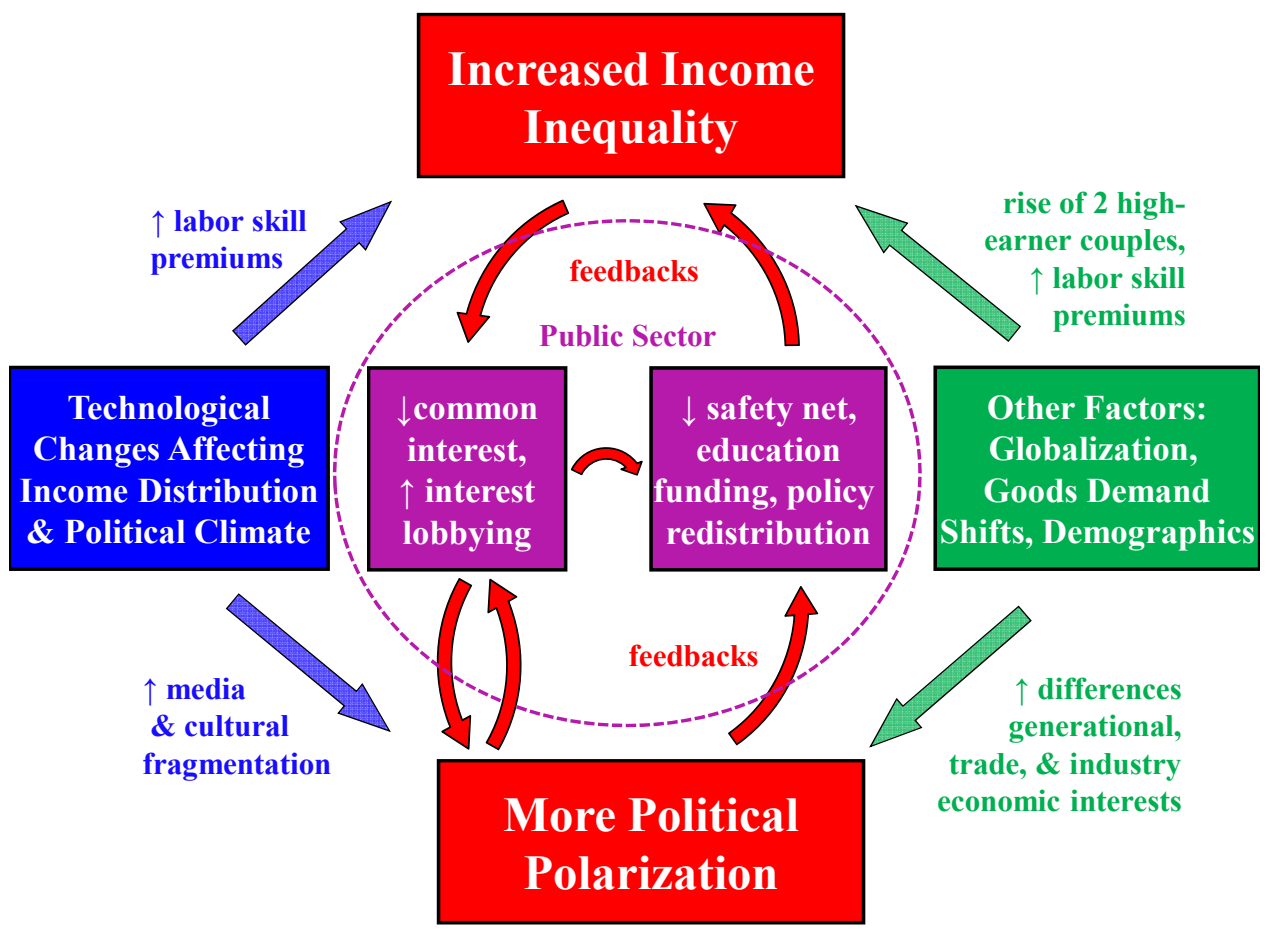

Figure 5: Influences on Income Inequality and Political Polarization 
Other, less technological changes-depicted in the box at the far right-have also contributed to increased inequality and political polarization. Shifts in demographic patterns, such as the more asymmetric sorting of people into pairs of highly educated couples have contributed to a less even distribution of income across families (e.g., Fernandez and Rogerson, 2001) and have reduced a sense of common political interests, possibly contributing to increased political polarization (see Mann and Ornstein, 2012, inter alia). In recent decades there has even been a shift to more income segregation across neighborhoods (Watson, 2009; Taylor and Fry, 2012) which may further reduce common interests. Other factors, such as the rise of globalization and shifts in goods demand towards new products (e.g., high tech) have also been linked to wider skill premiums and increased inequality (Dreher and Gaston, 2008; Cozzi and Impullitti, 2010). The rise of globalization has also been linked to a divergence in interests and voting behavior across socio- economic groups (Weck-Hanneman 2001), which may also induce greater political polarization. ${ }^{6}$

As stressed by Atkinson (2003) inter alia, changes in public policy have also contributed to increased income inequality. As depicted in the second from the right middle box in Figure 5, the shift to a smaller safety net and a less progressive income tax may have been factors, ${ }^{7}$ as have been limits on public support by the federal and state governments for higher education amid a rising share of young Americans attending college. To some extent, this may reflect a feedback from greater political polarization, where feedback effects between polarization and income inequality are depicted with red flow arrows in Figure 5. A reduced sense of common interest increases political polarization, which feeds back onto income inequality via less voter and legislative support for income redistribution and subsidies for higher education. Greater income inequality also more tightly concentrates economic interests among smaller and more cohesive

\footnotetext{
${ }^{6}$ For more on the various factors influencing the degree of political polarization, see Poole, McCarty, and Rosenthal (2002, 2006, forthcoming), Poole and Rosenthal (1984), and Rosenthal (2004).

${ }^{7}$ Doerrenberg and Peichl (2012) find that changes in government spending, but not taxation, had significantly lowered inequality in a panel of OECD nations. OECD (2011, p. 270) found little change in the net impact of U.S. benefits and taxes on inequality between 1979 and 2004 comparing disposable and before tax income.
} 
groups. This, in turn, enhances the power and influence of business and community groupswhich tend to support Republicans and Democrats, respectively-thereby inducing greater political polarization. The role played by factors affecting voter preferences is consistent with Poole and Rosenthal's (1997) finding that shifts in political polarization are less statistically linked to individual legislators changing their voting behavior ("conversions") and are more statistically linked to replacing members of Congress.

There are two major empirical implications of Figure 5. One is that income inequality and political polarization are not exogenous variables which are likely to be trendless or stationary. Several factors affect each or both of them, complicating how to interpret statistical relationships between them. Second, there are plausible bi-directional feedbacks, implying that inequality and political polarization may not be both statistically exogenous to each other.

\section{Estimating the Relationship Between Income Inequality and Political Polarization}

Increased partisanship in American politics has been attributed to shifting generational attitudes (Strauss and Howe, 1991), cyclical economic conditions (Gelman, et al., 2010; and Pontusson and Rueda, 2008), an increasingly fragmented state of media (e.g., Campante and Hojman, 2010; Davis and Owen, 2008; Duca and Saving, 2012a; Gul and Pesendorfer, 2012; Iyengar and Hahn, 2009; Jamieson and Cappella, 2008, Jones, 2001, and Prior, 2005 and 2007), and greater income inequality (e.g., Bartels (2008), Feddersen and Gul, 2013; McCarty, Poole, and Rosenthal 2006, forthcoming; and Stiglitz, 2012). ${ }^{8}$ The first of these factors is difficult to test with time series data owing to the low frequency of generational shifts, while the tendency of business cycles to reverse implies that economic cycles are unable to account for long-term shifts in polarization. This leaves two main testable long-run drivers: the increasingly fragmented state of American media and greater income inequality. The third factor has been measured over time with using the share of U.S. households having cable TV (Baum and Kernel, 1999; Duca and

\footnotetext{
${ }^{8}$ McCarty, Poole, and Rosenthal (2009) find that gerrymandering had little effect on polarization in the U.S. House.
} 
Saving, 2012a,b). Unfortunately, such data are limited to the era of TV and omit large, preWWII shifts in income inequality and political polarization. Until a measure of media fragmentation is devised that spans major new sources (i.e., newspapers, radio, and TV), analysis of this factor is limited to post-WWII sample periods (e.g., Duca and Saving, 2012a). Because we focus on a longer time period, our focus in this paper rests squarely on income inequality.

\section{IIIA. The Long-Run Variables Tracking Polarization and Income Inequality}

We consider four long-run variables available since 1913. These are the biennial Poole and Rosenthal indexes of polarization in the House and Senate (PolarH and PolarS, respectively) and biennial averages of Piketty and Saez's (2006) annual measures of the income share of the top 1 percent of families and the inverted Pareto-Lorenz coefficient. The latter are based on income inclusive of capital gains partly because the latter are affected by and have feedbacks on public policy, and partly because higher income families have incentives to alter the composition of reported labor and capital income depending on the tax code at different points in time. As Rosenthal (2004) notes, the House polarization index is more volatile than its Senate counterpart. Both are integrated of order 1, meaning that the first differences of each polarization index is stationary — as is the case for both inequality measures. Cointegration techniques for estimating long-run relationships between the levels of variables are suitable for I(1) variables. Accordingly, we estimate cointegration models of House and Senate polarization.

\section{IIIB. Empirical Approach to Testing for Long-Run Relationships}

Cointegration analysis is also amenable to testing whether right-hand side variables are exogenous to the dependent variable, providing evidence on whether income inequality drives political polarization and/or the reverse. We use vector-error correction models (VECMs) to jointly estimate the long-run relationship between two variables, $Y_{1}$ and $Y_{2}$ in a cointegrating vector and short-run effects in first difference equations, respectively:

$$
Y_{1}=\alpha_{0}+\alpha_{1} Y_{2}
$$




$$
\begin{aligned}
& \Delta Y_{1}=\beta_{1}\left[Y_{1}-\alpha_{0}+\alpha_{1} Y_{2}\right]_{\mathrm{t}-1}+\Sigma_{\mathrm{i}=1} \gamma_{\mathrm{i}} \Delta Y_{1 \mathrm{t}-\mathrm{i}}+\Sigma \delta_{\mathrm{i}} \Delta Y_{2 \mathrm{t}-\mathrm{i}}+\lambda_{1} X_{\mathrm{t}}+\varepsilon_{1 \mathrm{t}} \\
& \Delta \ln \left(Y_{2}\right)=\beta_{1}\left[\ln \left(Y_{1}\right)-\alpha_{0}+\alpha_{1} \ln \left(Y_{2}\right)\right]_{\mathrm{t}-1}+\Sigma_{\mathrm{i}=1} \gamma_{\mathrm{i}} \Delta \ln \left(Y_{2}\right)_{\mathrm{t}-\mathrm{i}}+\Sigma \delta_{\mathrm{i}} \Delta \ln \left(Y_{1}\right)_{\mathrm{t}-\mathrm{i}}+\lambda_{2} X_{\mathrm{t}}+\varepsilon_{2 \mathrm{t}}
\end{aligned}
$$

where the lags of first difference endogenous variables minimize the AIC, $X$ is a vector of exogenous factors, $\varepsilon_{\mathrm{it}}$ are residuals, and the $\lambda_{\mathrm{i}}, \gamma_{\mathrm{i}}$, and $\delta_{\mathrm{iv}}$ are row vectors of coefficients.

The estimation of long-run and short-run relationships is joint, and depends on which exogenous, short-run factors are included in the vector $X$. We tried several variables tracking possible effects of war deaths (with or without a dummy for the draft era), midterm congressional elections, the election of a new or reelection of an incumbent president (Pres2nd $=1$ for the first Congress following a president's re-election ${ }^{9}$ ), whether a president was being considered for impeachment (Impeach $=1$ for the 1973 and 1997 congresses) and first or second terms of a president. As was the case in Duca and Saving's (2012a) post-WWII study, none were consistently statistically significant, except for Pres2nd, which was statistically linked to higher polarization. This last finding may reflect hard feelings from a reelection campaign that spill over in the first Congress of a second term when incumbent presidents strive to remain relevant and the opposition party may try to lay the groundwork for regaining control of the presidency after the two-term limit precludes another reelection. ${ }^{10}$ In contrast to the House polarization index, the variable Impeach was consistently significant in models of Senate polarization. This may reflect the disparate consequences of the verdicts reached by the two chambers, with a "yes" in the House merely allowing the Senate to consider the issue (something all sides can potentially favor) but a "yes" in the Senate prompting a change of government. The finality of the Senate's decision on impeachment and the momentous nature of one branch of government removing an elected President from office could plausibly widen the partisan divide more in the Senate than the House.

\footnotetext{
${ }^{9}$ The definition omits the Congress after the 1964 election of Lyndon Johnson as he was president for less than a year before that election, during which he cast himself as following the agenda of an assassinated, popular president. ${ }^{10}$ 0-1 variables for controversial leaders (e.g., Nixon or the Gingrich led House), were significant but are omitted from the tables given their more arbitrary nature and that their inclusion did not affect the other qualitative results.
} 
We also tested a variable for the rise and fall of the New Deal, which may have reduced polarization by shifting the composition of the Democratic and Republican congressional delegations. The New Deal forged an unusually broad coalition of traditional limited government and pro-segregationist Southern Democrats with more interventionist, pro-civil rights Northern progressives. This increased the dispersion in voting within the Democratic congressional membership in the FDR and Truman presidencies, especially on economic matters and the role of the federal government, and reduced the ideological distance between that party and the Republicans. ${ }^{11}$ Because the Poole and Rosenthal polarization indexes track the spatial, ideological difference in the central voting patterns of the two parties with respect to the general role of government, this would be reflected in declines in the polarization indexes.

Analogously, the rise of polarization over the last half-century coincided with growing instability in that coalition between Northern liberals and Southern segregationists, the latter of whom shared more limited government sympathies on economic matters with Republicans, for whom they increasingly voted after the mid-1950s. Of course the Republicans were themselves divided into more and less conservative factions, the latter of which gradually moved in the other direction and became Democrats. This plausibly narrowed the ideological gap within the Democratic party, which in turn, acted to widen the spatial gap between the parties, leading to a rise in the measured polarization indexes.

This suggests one can plausibly single out the New Deal period as being fundamentally different as far as polarization is concerned. To capture these realignment effects, we added a 01 variable for the New Deal realignment effects which equaled 1 from the 1931 Congress (Hoover lost the mid-term 1930 mid-term election that elected the 1931 Congress) to the 1951 Congress, which coincided with the end of the Truman presidency, which was shortly followed

\footnotetext{
${ }^{11}$ This characterization is consistent with evidence from Achen and Bartels (2008) that the political realignment of the 1930s owed less to a shift in ideology among voters and more to their "retrospective" reaction in holding the Republican Party responsible for the Great Depression. They argue that, "the great partisan realignment of this period was largely due to a cumulation of myopic retrospections," (p. 7).
} 
by the 1954 Brown versus Board of Education ruling by the Supreme Court that further spurred the end of the old solid Democratic South. To control for this, we added a short-run control, NewDeal, which equals 1 for the 1931 to 1951 Congresses, to span all the Congresses during the FDR and Truman presidencies, plus the Congress elected in 1930, when the developing depression contributed to large Republican losses in House and Senate races in the North.

\section{IIIC. Tests of Whether the Inequality and Polarization Are Related in the Long-Run}

Cointegration tests for polarization in the House using four sets of short-run variables are reported in the uppermost panels of Tables 1 and 2, which use Top 1\% and the inverted ParetoLorenz coefficient to measure income inequality, respectively. In each table, Model 1 omits short-run variables and Model 2 includes Pres2nd, to which Model 3 adds NewDeal. Model 4 also adds Impeach to model 3. Although Impeach is insignificant, Model 4 is included to parallel the preferred Senate model that includes the same set of short-run variables. The VECMs estimated use data spanning the 1913-2009 Congresses. A lag length of 5 was used which was the minimum lag length needed to obtain a unique, significant cointegrating variable and, if possible, also yielded clean model residuals using the VECLM statistics on lags t-1 through $\mathrm{t}-6$. In cases when a statistically significant and unique cointegrating vector could not be identified, this lag length yielded the unique vector having the highest significance levels according to standard statistics. The estimation allowed for possible time trends in the long-run variables without an independent time effect in the vector not attributable to measured factors. The lagged first differences shorten the estimation periods to cover the 1925-2009 Congresses.

In every model and lag length shown using Top $1 \%$, a significant and unique cointegrating vector could be identified as implied by the eigenvalue and trace statistics rejecting the null hypothesis of no significant long-run relationship and by tests that accepted the null hypothesis of no more than 1 unique vector. By itself, this finding implies that there is a statistically significant and consistent relationship between polarization and Top1\%. However, another 
condition for an error-correction model to be valid is that the lagged error-correction term in the short-run model (lower panel of Table 1) be statistically significant and negative, implying that the time $t$ change in polarization tends to be negative if in the previous time period the actual level of polarization were above its equilibrium level. But in every case, the error-correction term is statistically insignificant, suggesting that long run deviations of polarization from the equilibrium levels implied by Top $1 \%$ do not help explain short-run changes in polarization.

Table 2 replaces Top $1 \%$ with the more theoretically grounded inverted Pareto-Lorenz measure of income inequality (IPL). In contrast to the Top 1\% results, only a marginally significant, unique cointegrating vector could be identified in Model 1. Nevertheless, in the presence of any of the statistically significant short-run factors a unique and statistically significant cointegrating vector could be identified in models 2-4. In contrast to the models in Table 1, a statistically significant and negative error-correction coefficient was estimated in Models 1-4, consistent with the notion that long-run relationships should have statistically significant information for short-run changes, as well as statistically significant information in cointegration tests. In this dimension, the results imply that there is more information about polarization in inequality measures that are more carefully and rigorously gauged, like $I P L$.

Tables 3 and 4 report Senate polarization models that use Top $1 \%$ and $I P L$, respectively. Models 1 and 2 include the same set of short-run variables across the Tables, with Models 4 and 5 in Tables 3 and 4 corresponding to Models 3 and 4 in Tables 1 and 2, respectively. Model 3 in Tables 3 and 4 only includes Pres2nd and Impeach as short-run factors. Applying the lag length selection criterion in the House models to the Senate polarization index implied a lag length of 4 in all Senate models, with an effective sample covering the 1923-2009 Congresses.

As with the House, there is more evidence that polarization in the Senate is more closely tied to inequality tracked by the inverted Pareto-Lorenz (IPL) coefficient than by the income share of the top $1 \%$. While a significant and statistically significant vector could be identified 
using Top 1\% in each model in Table 3, both the long-run coefficients on Top $1 \%$ and the errorcorrection coefficients are statistically insignificant in Models 1 and 2. Comparing model 3 in Tables 3 and 4 reveals that the long-run relationship is stronger using $I P L$ according to the tstatistic on this variable and the higher fit of that version of Model 3. The advantages of $I P L$ are more pronounced in models that include the New Deal realignment variable, as evidenced by speeds of adjustment that are about 7 percentage points faster per session and corrected Rsquares that are 0.13 to 0.14 higher than when Top $1 \%$ is used instead.

The estimated long-run coefficients for the best fitting House and Senate models both use the more justifiable $I P L$ rather than Top $1 \%$ to measure inequality, and include only the short-run variables that are significant in tracking polarization in each section of Congress. These vectors, from model 3 in Table 2 and model 4 in Table 4, imply that equilibrium polarization rises with income inequality as tracked by the inverted Pareto-Lorenz coefficient $(I P L)$ :

$$
\begin{aligned}
& \text { House: } \quad \text { Polar } H=-0.087+0.329 I P L^{* *}, \quad \text { (Model 3, Table 2) } \\
& \text { (8.67) } \\
& \text { Senate: } \quad \text { Polar } S=0.081+0.223 I P L^{* *} \quad \text { (Model 4, Table 4), }
\end{aligned}
$$

where t-statistics are in parentheses and ${ }^{* *}$ denotes significance at the $99 \%$ levels.

The respective House and Senate polarization indexes in Figures 6 and 7 weakly line up with the long-run equilibrium values from equations (2) and (3), adjusting for the constant in the short-run equation. The simple equilibrium relationships from these equations miss the Ushaped drops in polarization coinciding with the forming and fraying of the New Deal coalition. This can be viewed as a medium term effect spanning 10 congresses covered by the New Deal 0 1 variable. To adjust for this medium term effect, one can add to the respective equilibrium values the corresponding short-run coefficient on this discrete variable divided by the corresponding estimated speed of adjustment. The resulting equilibrium estimates line up well 


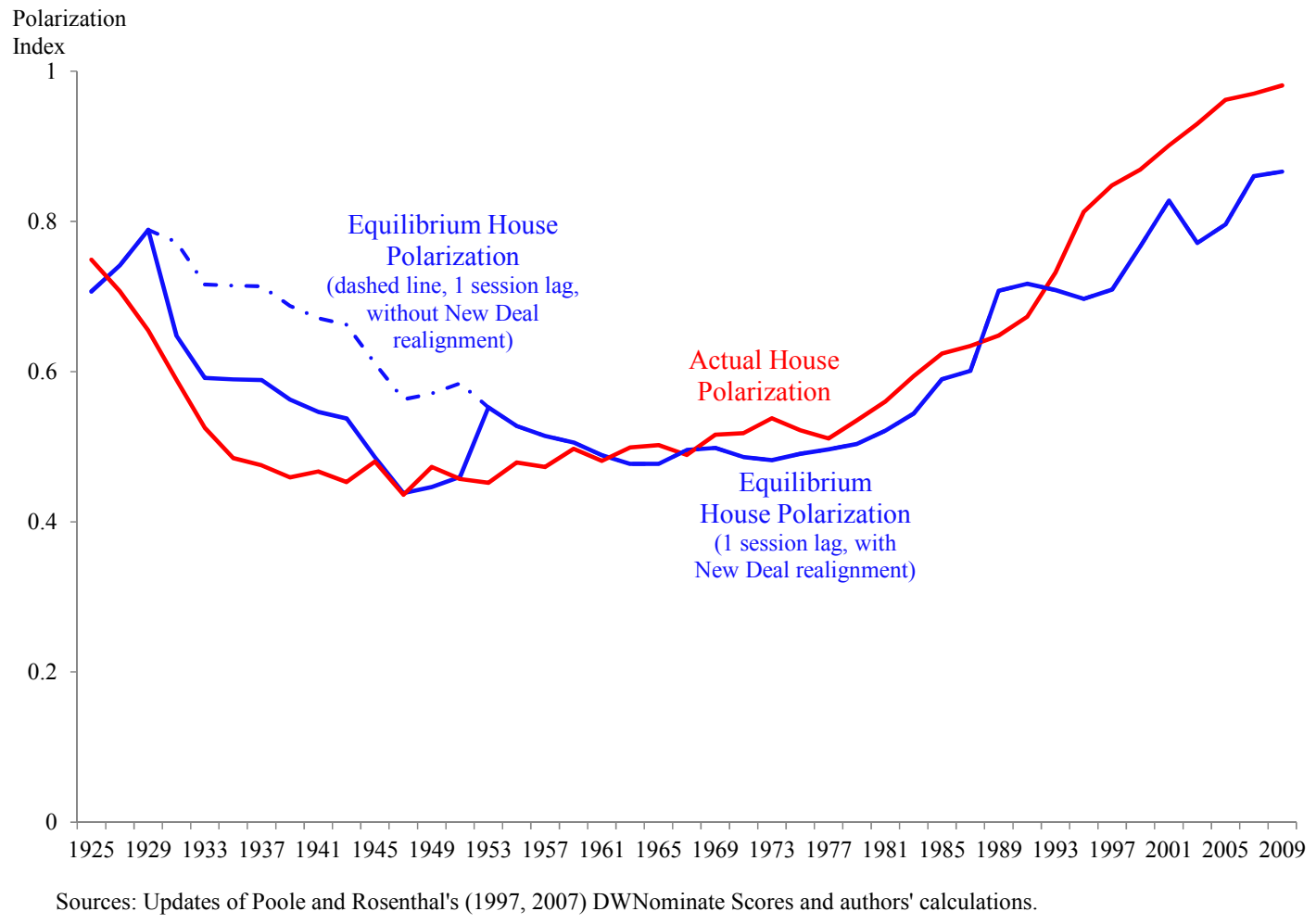

Figure 6: Inequality-Based Equilibrium Estimates Track House Polarization Trends Well

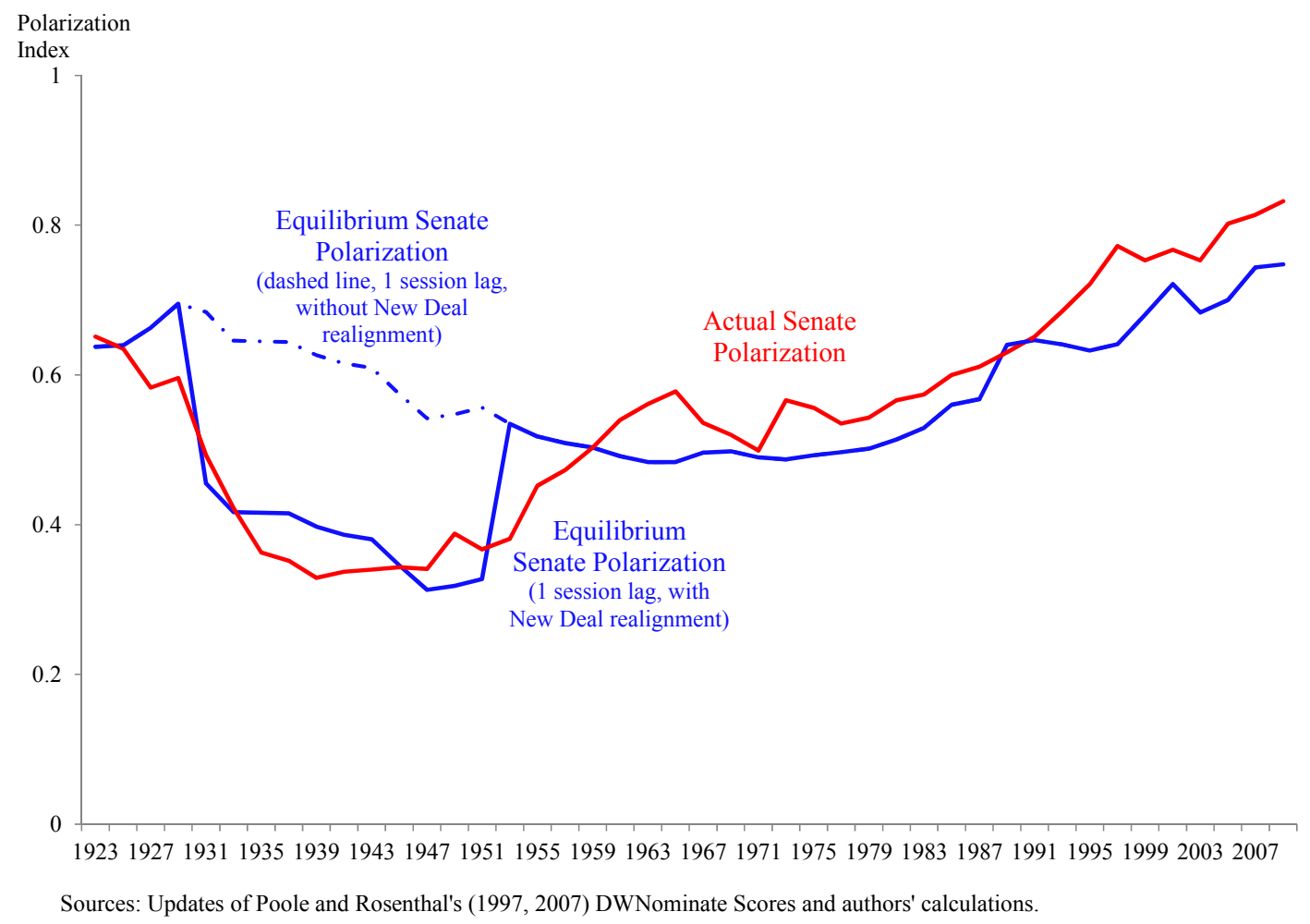

Figure 7: Inequality-Based Equilibrium Estimates Track Senate Polarization Trends Well 
with actual polarization indexes in Figures 6 and 7, in contrast to estimates lacking this realignment effect. Nevertheless, there is no clear pattern of the implied equilibrium levels leading actual polarization readings. This suggests there may be bidirectional feedbacks between inequality and polarization, an issue examined in Section IV.

\section{IIID. Tests of Whether the Inequality and Polarization Are Related in the Short-Run}

Results for the corresponding short-run models of the changes in House and Senate polarization are listed in the lower panels of Tables 2 and 4, respectively. Because the long-run information content of the top 1 percent share is much less informative than that from the more defensible inverted Pareto-Lorenz coefficient (IPL), the discussion of short-run effects will focus on those from models using IPL, reported in Tables 2 and 4. Additionally, the corrected Rsquares of corresponding House models are 5 to 8 percentage points higher using the IPL variable rather than the income share of the top 1 percent, and this advantage is even larger, ranging between 6 and 14 percent when comparing corresponding models of Senate polarization. The statistically significant, negative coefficients on the error-correction terms in these models imply that polarization falls in a congressional session if in the prior session polarization had been above the long-run equilibrium implied by its relationship with income inequality as tracked by $I P L$. One interesting pattern is the model fits are notably higher in models that include the highly significant New Deal realignment variable. This not only reflects the statistical significance of NewDeal, but also that the error-correction coefficients (speeds of adjustment) are higher and more significant. For example in model 3 of the House index, the magnitude of the error- or equilibrium-correction coefficient implies that about 16 percent of the gap between actual and equilibrium polarization is eliminated in the following congressional session. In Model 4 of Table 2, which is identical, except it includes NewDeal, the speed is higher at 23 percent. The impact of including the New Deal realignment variable on the estimated speed of adjustment is much larger for polarization in the Senate. The estimated speed 
of adjustment is 12.5 percent per session in model 3 in Table 4, which omits NewDeal, but more than doubles to 30.2 percent per session when NewDeal is added in model 4. The improvement in the estimated speed of adjustment also likely reflects that including NewDeal results in larger and more statistically significant long-run coefficients on the inequality variable, $I P L$, in the upper panel sections of Tables 2 and 4.

For both chambers of Congress, Pres2nd is statistically significant, with coefficients implying that the DW-Nominate index of House polarization rises by about 0.02 points and that of the Senate by a somewhat larger 0.03 to 0.04 points. The inclusion of this variable improves the fits of the House and Senate models by about .05 and .10 points, respectively, based on comparing the corrected R-square statistics of models 1 and 2 in Tables 2 and 4, respectively. While Impeach is insignificant in the House polarization model 4, it is significant in the two Senate models (3 and 4) shown in Table 4, with coefficients implying that impeachment proceedings increase polarization in the Senate by about 0.05 index points.

\section{Is Income Inequality Exogenous to Polarization? Is there Bidirectional Causation?}

As discussed earlier in Section 2, both income inequality and political polarization are likely affected by several variables in the long-run. Moreover, the long-run causation need not just be from income inequality to political polarization mainly because inequality has been found to be affected by shifts in public policy that may reflect the effects of polarization on government spending, taxes, and trade policy. Partly to examine empirically whether causation between these two variables might be bi-directional, the models presented earlier were estimated as a vector error-correction model containing separate equations for changes in polarization and income inequality, which were regressed on the same error-correction term, the same lags of changes in the long-run variables and the choice of any short-run variable(s). If the errorcorrection term is significant in the model of polarization but is insignificant in the model of inequality, then formal econometric evidence indicates that income inequality is 'weakly 
exogenous' to polarization as discussed in Urbain (1992) and which Granger and Lin (1995)

would have described as evidence that income inequality is caused, in a long-run sense, by political polarization.

As reported in Table 5, income inequality "causes" polarization, with one case where the evidence is marginally significant. For the House, there is statistically significant evidence that polarization "causes" income inequality. For the Senate, there is statistically significant evidence that polarization "causes" income inequality in the absence of controls for New Deal realignment effects, and weak or marginally significant evidence in the presence of such controls. In other models that replace the inverted Pareto-Lorenz coefficient $(I P L)$ with the top $1 \%$ income share (not shown to conserve space), the evidence is stronger for causality running from polarization to inequality and less strong for causality running from inequality to polarization. This may reflect either that the top 1 percent share is more prone to measurement error or that the special interest lobbying is both encouraged in a highly polarized environment and tends to favor the extremely rich, as tracked by the income share of the top 1 percent. In general, the statistical evidence suggests bidirectional effects or important feedbacks between income inequality and polarization that are illustrated in Figure 5. This is consistent with the view that increased inequality makes it more difficult to achieve political consensus either through undermining a sense of common interest or through fostering more rent-seeking, and that polarization undermines support for redistributive policies, thereby inducing greater inequality.

\section{Conclusion}

Using time-series techniques appropriate for analyzing variables with shifting long-run trends, this paper examines the statistical relationships between income inequality and the congressional polarization indexes of Poole and Rosenthal, both of which have trended up sharply in recent decades. While public discussion of a possible relationship has focused on tracking income inequality with the income share of the top earning 1 percent of families, this 
measure is noisy and may not accurately track inequality as well as other measures, such as the inverted Pareto-Lorenz coefficient, as demonstrated in Atkinson, et al. (2011). Indeed, absent a control for New Deal political realignment effects, information from the long-run relationship between income inequality and political polarization does not consistently add statistically significant information about short-run changes in House and Senate polarization using data from the 1913-2009 congresses sample if inequality is measured by the top 1 percent income share. However, it adds information using the more accurate gauge of income inequality, the inverted Pareto-Lorenz coefficient. While both income inequality measures are cointegrated with polarization, models of the short-run change in polarization that employ the more precise inequality measure outperform those using the income share of the top 1 percent of families. These results reflect the advantage of using more precise and accurate gauges of income inequality, as stressed by Atkinson (2003) and Atkinson, et al. (2011), that match the care and precision taken by Poole and Rosenthal $(1997,2007)$ in measuring political polarization.

A second interesting finding is the statistically significant pattern of increased political polarization in the congressional term immediately following the reelection of a president. This this variable is significant in contrast to a similar $0-1$ variable for the term following a president's initial election. Perhaps these patterns reflect not so much that new presidents benefit from a "honeymoon" period in their first congressional session, as much as recently reelected presidents may suffer a congressional backlash effect, which might stem from the opposing party trying to either limit the over-reach of a reelected president or stymie a reelected president's initiatives in order to benefit in the next presidential election.

A third, important contribution of this paper is in documenting the existence of long-run, bi-directional feedback effects between income inequality and political polarization. This finding is consistent with the view that both income inequality and political polarization are endogenous variables that feedback on each other (Bartels, 2008; McCarty, Poole, and 
Rosenthal, 2002, 2006, 2009, forthcoming). Perhaps the three most plausible of these are, on the one hand, that increased income inequality (1) weakens the perception of shared destiny and thereby spawns political polarization, (2) through concentrating the gains from lobbying induces more special interest rent-seeking by some of the very wealthy, or (3) fosters a perception that one's political opponents are working against the national interest, which limits support for social-insurance programs that encompass all segments of American society.

Aside from these three contributions to the empirical literature, this study's results have other political-economic implications. Several factors have been hypothesized to affect the degree of political polarization in the U.S., of which income inequality and media fragmentation have been empirically tested using post WWII sample periods [e.g., Baum and Kernel (1999), Duca and Saving (2012a), McCarty, Poole, and Rosenthal (2006, forthcoming), and Prior (2007)]. Although the lack, so far, of pre-1950 data on media fragmentation preclude an historically lengthier test of the relative importance of media and inequality trends as drivers of polarization, recent trends in cable TV penetration and income inequality do not seem to have reversed. With respect to the latter factor, the results of the current study suggest that until other structural changes affecting income inequality or inducing political reform or realignment occur, a high degree of polarization in congressional voting is likely to persist. In this apparent likely scenario, continued political polarization could have major economic implications. For example, the lack of political consensus for addressing the U.S.'s long-run fiscal challenges was the main rationale mentioned by Standard \& Poor's (2011) when it downgraded the credit rating of U.S. Treasury debt. The challenges posed by entitlement programs (not to mention the current national debt) have only become worse in the ensuing period, with no clear indication of how or even whether legislators will bridge their differences - and whether voters will even allow them to do so. 


\section{References}

Achen, Christopher H. and Bartels, Larry (2008), "Myopic Retrospection and Party Realignment in the Great Depression," manuscript, Princeton University.

Atkinson, Anthony B. (2003), "Income Inequality in OECD Countries: Data and Explanations," CESifo Working Paper Series 881.

Atkinson, Anthony B., Piketty, Thomas, and Saez, Emmanuel (2011), “Top Incomes in the Long-Run of History," Journal of Economic Literature 49, 3-71.

Bartels, Larry M. (2008), Unequal Democracy: The Political Economy of the New Gilded Age, New York: Russell Sage Foundation, and Princeton, NJ: Princeton University Press.

Baum, Matthew and Samuel Kernell (1999), "Has Cable Ended the Golden Age of Presidential Television?" American Political Science Review 93, 99-114.

Benhabib, Seyla (1996), ‘Toward a Deliberative Model of Democratic Legitimacy', in S. Benhabib (ed.) Democracy and Difference: Contesting the Boundaries of the Political. Princeton University Press, Princeton, New Jersey, 67-94.

Campante, Filipe R. and Daniel Hojman (2010), “Media and Polarization,” Harvard Kennedy School Faculty Research Working Paper Series RWP10-002.

Cozzi, Guido, and Giammario Impullitti (2010), “Government Spending Composition, Technical Change, and Wage Inequality," Journal of the European Economic Association 8, $1325-1358$.

Davis, Richard, and Diana Owen (1998), New Media and American Politics, Oxford University Press: Oxford.

Doerrenberg, Phillippe and Andreas Peichl (2012), “The Impact of Redistributive Policies on Inequality in OECD Countries," IZA Discussion Paper No. 6505, April.

Downs, Anthony (1957), An Economic Theory of Democracy, Harper, New York.

Dreher, Axel, and Noel Gaston (2008), "Has Globalization Increased Inequality?” Review of 
International Economics 16, 516-536.

Duca, John V. and Jason L. Saving (2012a), “Has Income Inequality or Media Fragmentation Increased Political Polarization?” unpublished manuscript, Southern Methodist University, August 2012.

Duca, John V. and Jason L. Saving (2012b), "The Increasingly Media Fragmented and Opinionated American Public," unpublished manuscript, Southern Methodist University, June 2012.

Engle, Robert F. and Clive W.J. Granger (1987) "Co-integration and Error Correction: Representation, Estimation, and Testing," Econometrica 55, 251-276.

Feddersen, Tim and Faruk Gul (2013), "Polarization and Income Inequality: A Model of Unequal Democracy," Princeton University, April.

Fernandez, Raquel, and Richard Rogerson (2001), “Sorting and Long-Run Inequality,” Quarterly Journal of Economics 1164, 1305-1341.

Foote, Joe S. (1988), "Ratings Decline of Presidential Television,” Journal of Broadcasting and Electronic Media 32, 225-230.

Gelman, Andrew, Lane Kenworthy, and Yu-Sung Su (2010), "Income Inequality and Partisan Voting in the United States," Social Science Quarterly 91, 1203-1219.

Gimmler, Antje (2001), "Deliberative democracy, the public sphere, and the Internet," Philosophy and Social Criticism 27(4), 21-39.

Goldin, Claudia and Lawrence F. Katz (2007), "Long-Run Changes in the Wage Structure: Narrowing, Widening, Polarizing," Brookings Papers on Economic Activity 2:2007, 13565.

Granger, Clive W.J. and Jin-Lung Lin (1995), “Causality in the Long-Run,” Econometric Theory $11,530-536$.

Gul, Faruk and Wolfgang Pesendorfer (2012), "Media and Policy," manuscript, Princeton 
University, September.

Iyengar, Shanto, and Kyu S. Hahn (2009), “Red Media, Blue Media: Evidence of Ideological Selectivity in Media Use," Journal of Communication 59, 19-39.

Jamieson, Kathleen H., and Joseph N. Cappella (2008), Echo Chamber, Oxford University Press, New York.

Johansen, S. (1991), “Estimation and Hypothesis Testing of Cointegration Vectors in Gaussian Vector Autoregressive Models,” Econometrica 59, 1551-1580.

Johansen, S. and Juselius, K. (1990), “Maximum Likelihood Estimation and Inference on Cointegration - with Applications to the Demand for Money", Oxford Bulletin of Economics and Statistics 52, 169-210.

Jones, David A. (2001), “The Polarizing Effect of New Media Messages,” International Journal of Public Opinion Research 14, 158-174.

Lemieux, Thomas (2006), "Postsecondary Education and Increased Wage Inequality." American Economic Review 96, 195-99.

Mann, Thomas E. and Norman J. Ornstein (2012), It's Even Worse Than It Looks: How the American Constitutional System Collided with the New Politics of Extremism, Basic Books, New York.

McCarty, Nolan (2010), “Measuring Legislative Preferences,” manuscript, Princeton University. McCarty, Nolan, Keith T. Poole, and Howard Rosenthal (2009), "Does Gerrymandering Cause Polarization?” American Journal of Political Science 53, 666-680.

McCarty, Nolan M., Poole, Keith T., and Rosenthal, Howard (forthcoming), Political Bubbles: Financial Crises and the Failure of American Democracy, Princeton University Press, Princeton, New Jersey.

McCarty, Nolan M., Poole, Keith T., and Rosenthal, Howard (2006), Polarized America: The Dance of Ideology and Unequal Riches, MIT Press, Cambridge, Massachusetts. 
McCarty, Nolan, Keith T. Poole, and Howard Rosenthal. 2002. "Political Polarization and Income Inequality," Russell Sage Foundation Working Paper.

Mian, A., A. Sufi, and F. Trebbi (2012), "Resolving Debt Overhang: Political Constraints in the Aftermath of Financial Crises," American Economic Association conference paper, January 2012, <www.aeaweb.org/aea/2012conference/program/retrieve.php?pdfid >.

OECD (2011), Divided We Stand: Why Inequality Keeps Rising, OECD, Paris.

Piketty, Thomas and Saez, Emmanuel (2006), “The Evolution of Top Incomes: A Historical and International Perspective," American Economic Review 96, 200-05.

Pontusson, Jonas, and David Rueda (2008), "Inequality as a Source of Political Polarization: A Comparative Analysis of Twelve OECD Countries," in Pablo Beramendi and Christopher J. Anderson ed., Democracy, Inequality, and Representation. Russell Sage Foundation, New York.

Poole, Keith T., and Howard Rosenthal (1997), Congress: A Political-Economic History of Roll Call Voting, Oxford University Press, New York.

Poole, Keith T., and Howard Rosenthal (2007), Ideology and Congress, Transaction Publishers, New Brunswick, New Jersey.

Poole, Keith T. and Howard Rosenthal (1984), “The Polarization of American Politics,” Journal of Politics 46, 1061-79.

Popkin, Samuel L. (1991), The Reasoning Voter: Communication and Persuasion in Presidential Campaigns, University of Chicago Press, Chicago.

Prior, Marcus (2005), “News vs. Entertainment: How Increasing Media Choice Widens Gaps in Political Knowledge and Turnout," American Journal of Political Science 49, 577-92.

Prior, Markus (2007), Post-Broadcast Democracy: How Media Choice Increases Inequality in Political Involvement and Polarizes Elections, Cambridge University Press, Cambridge, UK. 
Rosenthal, Howard (2004), "Politics, Public Policy, and Inequality: A Look Back at the Twentieth Century," in Social Inequality, ed. Kathryn M. Neckerman, Russell Sage Foundation,New York, 861-92.

Standard and Poors (2011), 'United States of America Long-Term Rating Lowered To 'AA+' Due To Political Risks, Rising Debt Burden; Outlook Negative," August 5, 2011, http:/www.standardandpoors.com/ratings/articles/en/us/?assetID=1245316529563.

Stiglitz, Joseph E. (2012), The Price of Inequality, W. W. Norton \& Company, New York.

Strauss, William and Neil Howe (1991), Generations: The History of America's Future 15842069, William Morrow, New York.

Sunstein, Cass (2007), Republic.com 2.0, Princeton University Press, Princeton, New Jersey.

Taylor, Paul and Richard Fry (2012), “The Rise of Residential Segregation by Income,” Special Report, Pew Social \& Demographic Trends, August.

Tewksbury, David (2005), "The Seeds of Audience Fragmentation: Specialization in the Use of Online News Sites," Journal of Broadcasting and Electronic Media 49: 332-348.

Urbain, Jean-Pierre (1992), “On Weak Exogeneity in Error Correction Models” Oxford Bulletin of Economics and Statistics 54, 187-207.

Watson, Tara (2009), "Inequality and the Measurement of Residential Segregation by Income in American Neighborhoods," Review of Income and Wealth 55, 820-844.

Weck-Hannemann, Hannelore (2001), “Globalization as a Challenge for Public Choice Theory," Public Choice 106, 77-92. 
Table 1: Biennial Models of Political Polarization in the U.S. House of Representatives Using the Income Share of the Top $1 \%$ to Measure Inequality

(1913-2009 Congresses spanning votes over 1913-2010)

Equilibrium Long-Run Relationship: Polar $_{\mathrm{t}}=\lambda_{0}+\lambda_{1}$ Top $1 \% \mathrm{t}-1$

\begin{tabular}{|c|c|c|c|c|}
\hline & Model 1 & Model 2 & Model 3 & Model 4 \\
\hline Constant & -0.0200 & 0.2281 & $\overline{0.2094}$ & 0.2071 \\
\hline Top $1 \% o_{\mathrm{t}-1}$ & $\begin{array}{l}0.0266^{* *} \\
(7.18)\end{array}$ & $\begin{array}{l}0.0267^{* *} \\
(7.03)\end{array}$ & $\begin{array}{l}0.0280^{* *} \\
(6.01)\end{array}$ & $\begin{array}{l}0.0281^{* *} \\
(6.14)\end{array}$ \\
\hline Eig. (1 vector) & 0.276 & 0.358 & 0.344 & 0.351 \\
\hline Eig. (2 vectors) & 0.015 & 0.004 & 0.009 & 0.001 \\
\hline Trace (1 vector) & $14.54^{+}$ & $20.80^{* *}$ & $18.56^{*}$ & $19.05^{*}$ \\
\hline Trace (2 vectors) & 0.64 & 1.74 & 0.41 & 0.42 \\
\hline Max-Eig (1 vector) & $14.26^{+}$ & $19.06^{* *}$ & $18.15^{*}$ & $18.62^{* *}$ \\
\hline Max-Eig (2 vectors) & 0.64 & 1.74 & 0.41 & 0.42 \\
\hline Cointegration? & $\mathrm{Yes}^{+}$ & $\mathrm{Yes}^{* *}$ & Yes $^{*}$ & $\mathrm{Yes}^{* * * *}$ \\
\hline
\end{tabular}

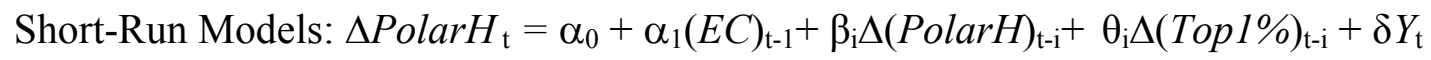

\begin{tabular}{|c|c|c|c|c|}
\hline $\begin{array}{l}\text { Sample } \\
\text { Variable }\end{array}$ & $\begin{array}{l}1925-2009 \\
\text { Model 1 } \\
\end{array}$ & $\begin{array}{l}1925-2009 \\
\text { Model 2 } \\
\end{array}$ & $\begin{array}{l}\text { 1925-2009 } \\
\text { Model } 3 \\
\end{array}$ & $\begin{array}{l}1925-2009 \\
\text { Model } 4 \\
\end{array}$ \\
\hline Constant & $\begin{array}{l}0.0015 \\
(0.40)\end{array}$ & $\begin{array}{l}-0.0013 \\
(-0.34)\end{array}$ & $\begin{array}{l}0.0030 \\
(0.55)\end{array}$ & $\begin{array}{l}0.0033 \\
(0.61)\end{array}$ \\
\hline$E C_{\mathrm{t}-1}$ & $\begin{array}{l}-0.120 \\
(-1.47)\end{array}$ & $\begin{array}{l}-0.105 \\
(-1.33)\end{array}$ & $\begin{array}{l}-0.139 \\
(-1.60)\end{array}$ & $\begin{array}{l}-0.130 \\
(-1.45)\end{array}$ \\
\hline $\operatorname{Pres} 2 n d_{\mathrm{t}}$ & & $\begin{array}{l}0.019^{+} \\
(1.74)\end{array}$ & $\begin{array}{l}0.019^{+} \\
(1.80)\end{array}$ & $\begin{array}{l}0.020^{+} \\
(1.84)\end{array}$ \\
\hline Impeach $_{\mathrm{t}}$ & & & & $\begin{array}{l}-0.011 \\
(-0.59)\end{array}$ \\
\hline $\mathrm{NewDeal}_{\mathrm{t}}$ & & & $\begin{array}{l}-0.016 \\
(-1.15)\end{array}$ & $\begin{array}{l}-0.016 \\
(-1.12)\end{array}$ \\
\hline$\Delta$ PolarH $_{\mathrm{t}-1}$ & $\begin{array}{l}0.422^{* *} \\
(2.62)\end{array}$ & $\begin{array}{c}0.378^{*} \\
(2.38)\end{array}$ & $\begin{array}{l}0.385^{*} \\
(2.43)\end{array}$ & $\begin{array}{l}0.401^{*} \\
(2.46)\end{array}$ \\
\hline$\Delta$ PolarH $_{-2}$ & $\begin{array}{l}0.533^{* *} \\
(3.11)\end{array}$ & $\begin{array}{l}0.475^{* *} \\
(2.81)\end{array}$ & $\begin{array}{l}0.471^{* *} \\
(2.78)\end{array}$ & $\begin{array}{l}0.493^{* *} \\
(2.81)\end{array}$ \\
\hline$\Delta$ PolarH $_{\mathrm{t}-3}$ & $\begin{array}{l}-0.048 \\
(-0.26)\end{array}$ & $\begin{array}{l}0.058 \\
(0.31)\end{array}$ & $\begin{array}{l}0.077 \\
(0.41)\end{array}$ & $\begin{array}{l}0.052 \\
(0.27)\end{array}$ \\
\hline$\Delta$ PolarH $_{\mathrm{t}-4}$ & 0.067 & 0.021 & -0.015 & -0.037 \\
\hline
\end{tabular}




\begin{tabular}{|c|c|c|c|c|}
\hline & $(0.37)$ & $(0.11)$ & $(-0.08)$ & $(-0.20)$ \\
\hline$\Delta$ PolarH $_{\mathrm{t}-5}$ & $\begin{array}{l}0.343^{+} \\
(1.88)\end{array}$ & $\begin{array}{c}0.330^{+} \\
(1.86)\end{array}$ & $\begin{array}{l}0.292^{+} \\
(1.62)\end{array}$ & $\begin{array}{l}0.291 \\
(1.60)\end{array}$ \\
\hline$\Delta T o p 1 \%{ }_{\mathrm{t}-1}$ & $\begin{array}{l}-0.0025 \\
(-0.95)\end{array}$ & $\begin{array}{l}-0.0034 \\
(-1.30)\end{array}$ & $\begin{array}{l}-0.0045^{+} \\
(-1.65)\end{array}$ & $\begin{array}{l}-0.0044 \\
(-1.60)\end{array}$ \\
\hline$\Delta T o p 1 \% \%_{\mathrm{t}-2}$ & $\begin{array}{l}-0.0019 \\
(-0.71)\end{array}$ & $\begin{array}{r}-0.0005 \\
(-0.19)\end{array}$ & $\begin{array}{l}-0.0012 \\
(-0.44)\end{array}$ & $\begin{array}{l}-0.0014 \\
(-0.49)\end{array}$ \\
\hline$\Delta T o p 1 \%{ }_{\mathrm{t}-3}$ & $\begin{array}{l}-0.0006 \\
(-0.19)\end{array}$ & $\begin{array}{r}-0.0019 \\
(-0.43)\end{array}$ & $\begin{array}{r}-0.0013 \\
(-0.41)\end{array}$ & $\begin{array}{r}-0.0012 \\
(-0.39)\end{array}$ \\
\hline$\Delta T o p 1 \% \mathrm{t}_{\mathrm{t}-4}$ & $\begin{array}{l}-0.0021 \\
(-0.78)\end{array}$ & $\begin{array}{l}-0.0010 \\
(-0.36)\end{array}$ & $\begin{array}{l}-0.0013 \\
(-0.47)\end{array}$ & $\begin{array}{r}-0.0013 \\
(-0.47)\end{array}$ \\
\hline$\Delta T o p 1 \% \%_{\mathrm{t}-5}$ & $\begin{array}{l}0.0039 \\
(1.29)\end{array}$ & $\begin{array}{l}0.0022 \\
(0.72)\end{array}$ & $\begin{array}{l}0.0030 \\
(0.92) \\
\end{array}$ & $\begin{array}{l}0.0028 \\
(0.86)\end{array}$ \\
\hline Adjusted $\mathrm{R}^{2}$ & .452 & .486 & .487 & .475 \\
\hline S.E. & 0.0233 & 0.0226 & 0.0226 & 0.0228 \\
\hline VECLM(1) & 2.36 & 2.56 & 2.70 & 4.21 \\
\hline VECLM(6) & 2.22 & 2.04 & 1.96 & 2.35 \\
\hline
\end{tabular}

\section{Augmented Dickey-Fuller Unit Root Tests Using Schwartz Information Criterion (1913-2009 Congresses, covering 1913-2010)}

\section{Level (SIC lag)}

$\begin{array}{llll}\text { PolarH } & -0.3008 & (0) & \Delta \text { PolarH } \\ \text { PolarS } & -1.1704 & (0) & \Delta \text { PolarS } \\ \text { IPL } & -1.6126 & (0) & \Delta I P L \\ \text { Top } 1 \% & -0.4310 & (2) & \Delta \text { Top } 1 \%\end{array}$

Level (SIC lag)

$-5.9251^{* *} \quad(0)$

$-5.6222^{* *}$

$-6.7444^{* *}$

Notes: ${ }^{+},{ }^{*}$ and ${ }^{* *}$ denote $90 \%, 95 \%$, and $99 \%$ significance levels, respectively. t-statistics in parentheses. Lag lengths of 5 yielded the strongest evidence for unique, significant vectors. The significance level of VECLM statistics accounts for size of the vector. Lag lengths for unit root tests are based on the Schwartz Information. 
Table 2: Biennial Models of Political Polarization in the U.S. House of Representatives Using the Preferable Inverted Pareto-Lorenz Measure of Inequality

(1913-2009 Congresses spanning votes over 1913-2010)

Equilibrium Long-Run Relationship: $\operatorname{Polar}_{\mathrm{t}}=\lambda_{0}+\lambda_{1} I P L_{\mathrm{t}-1}$

\begin{tabular}{|c|c|c|c|c|}
\hline & Model 1 & Model 2 & Model 3 & Model 4 \\
\hline Constant & $\overline{-0.0200}$ & -0.0038 & -0.0865 & -0.0856 \\
\hline$I P L_{\mathrm{t}-1}$ & $\begin{array}{l}0.2969^{* *} \\
(6.68)\end{array}$ & $\begin{array}{l}0.2892^{* *} \\
(6.26)\end{array}$ & $\begin{array}{l}0.3286^{* *} \\
(8.67)\end{array}$ & $\begin{array}{l}0.3282^{\text {** }} \\
(8.37)\end{array}$ \\
\hline Eig. (1 vector) & 0.276 & 0.295 & 0.344 & 0.328 \\
\hline Eig. (2 vectors) & 0.015 & 0.020 & 0.000 & 0.001 \\
\hline Trace (1 vector) & $14.54^{+}$ & $15.89^{*}$ & $18.17^{*}$ & $17.09^{*}$ \\
\hline Trace (2 vectors) & 0.64 & 0.83 & 0.02 & 0.02 \\
\hline Max-Eig (1 vector) & $14.26^{+}$ & $15.02^{*}$ & $18.16^{*}$ & $17.07^{*}$ \\
\hline Max-Eig (2 vectors) & 0.64 & 0.87 & 0.02 & 0.02 \\
\hline Cointegration? & $\mathrm{Yes}^{+}$ & Yes $^{*}$ & Yes $^{*}$ & Yes $^{*}$ \\
\hline
\end{tabular}

Short-Run Models: $\Delta$ PolarH $_{\mathrm{t}}=\alpha_{0}+\alpha_{1}(E C)_{\mathrm{t}-1}+\beta_{\mathrm{i}} \Delta\left(\right.$ PolarH $_{\mathrm{t}-\mathrm{i}}+\theta_{\mathrm{i}} \Delta(I P L)_{\mathrm{t}-\mathrm{i}}+\delta Y_{\mathrm{t}}$

\begin{tabular}{|c|c|c|c|c|}
\hline $\begin{array}{l}\text { Sample } \\
\text { Variable }\end{array}$ & $\begin{array}{l}\text { 1925-2009 } \\
\text { Model } 1\end{array}$ & $\begin{array}{l}1925-2009 \\
\text { Model } 2 \\
\end{array}$ & $\begin{array}{l}1925-2009 \\
\text { Model } 3 \\
\end{array}$ & $\begin{array}{l}1925-200 \\
\text { Model } 4 \\
\end{array}$ \\
\hline Constant & $\begin{array}{l}0.0024 \\
(0.67)\end{array}$ & $\begin{array}{l}-0.0014 \\
(-0.36)\end{array}$ & $\begin{array}{l}0.0067 \\
(1.26)\end{array}$ & $\begin{array}{l}0.0067 \\
(1.27)\end{array}$ \\
\hline$E C_{\mathrm{t}-1}$ & $\begin{array}{l}-0.157^{*} \\
(-2.24)\end{array}$ & $\begin{array}{l}-0.160^{*} \\
(-2.41)\end{array}$ & $\begin{array}{c}-0.233^{* *} \\
(-3.03)\end{array}$ & $\begin{array}{l}-0.226^{* *} \\
(-2.83)\end{array}$ \\
\hline $\operatorname{Pres} 2 n d_{\mathrm{t}}$ & & $\begin{array}{l}0.021^{*} \\
(2.02)\end{array}$ & $\begin{array}{l}0.022^{*} \\
(2.16)\end{array}$ & $\begin{array}{l}0.022^{*} \\
(2.17)\end{array}$ \\
\hline Impeach $_{\mathrm{t}}$ & & & & $\begin{array}{l}-0.008 \\
(-0.44)\end{array}$ \\
\hline NewDeal & & & $\begin{array}{l}-0.029^{*} \\
(-2.09)\end{array}$ & $\begin{array}{l}-0.029^{*} \\
(-2.02)\end{array}$ \\
\hline$\Delta$ Polar $_{\mathrm{t}-1}$ & $\begin{array}{l}0.316^{+} \\
(1.96)\end{array}$ & $\begin{array}{c}0.289^{+} \\
(1.88)\end{array}$ & $\begin{array}{l}0.269^{+} \\
(1.79)\end{array}$ & $\begin{array}{l}0.281^{+} \\
(1.82)\end{array}$ \\
\hline$\Delta$ PolarH $_{-2}$ & $\begin{array}{l}0.504^{* *} \\
(3.11)\end{array}$ & $\begin{array}{l}0.486^{* *} \\
(3.15)\end{array}$ & $\begin{array}{l}0.445^{* *} \\
(2.94)\end{array}$ & $\begin{array}{l}0.458^{* *} \\
(2.93)\end{array}$ \\
\hline$\Delta$ PolarH $_{\mathrm{t}-3}$ & $\begin{array}{l}0.013 \\
(0.07)\end{array}$ & $\begin{array}{l}0.099 \\
(0.57)\end{array}$ & $\begin{array}{l}0.172 \\
(1.01)\end{array}$ & $\begin{array}{l}0.156 \\
(0.89)\end{array}$ \\
\hline$\Delta$ PolarH $_{\mathrm{t}-4}$ & $\begin{array}{c}0.572 \\
(0.33)\end{array}$ & $\begin{array}{l}0.019 \\
(0.11)\end{array}$ & $\begin{array}{l}-0.032 \\
(-0.20)\end{array}$ & $\begin{array}{l}-0.047 \\
(-0.28)\end{array}$ \\
\hline
\end{tabular}




\begin{tabular}{|c|c|c|c|c|}
\hline$\Delta$ PolarH $_{\mathrm{t}-5}$ & $\begin{array}{l}0.423^{*} \\
(2.48)\end{array}$ & $\begin{array}{l}0.396^{*} \\
(2.43)\end{array}$ & $\begin{array}{l}0.337^{*} \\
(2.13)\end{array}$ & $\begin{array}{l}0.335^{*} \\
(-2.09)\end{array}$ \\
\hline$\Delta I P L_{\mathrm{t}-1}$ & $\begin{array}{l}-0.021 \\
(-0.52)\end{array}$ & $\begin{array}{l}-0.027 \\
(-0.70)\end{array}$ & $\begin{array}{l}-0.055 \\
(-1.42)\end{array}$ & $\begin{array}{l}-0.055 \\
(-1.40)\end{array}$ \\
\hline$\Delta I P L_{\mathrm{t}-2}$ & $\begin{array}{l}-0.012 \\
(-0.29)\end{array}$ & $\begin{array}{l}0.100 \\
(0.26)\end{array}$ & $\begin{array}{l}-0.004 \\
(-0.11)\end{array}$ & $\begin{array}{l}-0.004 \\
(-0.11)\end{array}$ \\
\hline$\Delta I P L_{\mathrm{t}-3}$ & $\begin{array}{l}-0.002 \\
(-0.05)\end{array}$ & $\begin{array}{l}0.015 \\
(0.38)\end{array}$ & $\begin{array}{l}0.008 \\
(0.19)\end{array}$ & $\begin{array}{l}0.008 \\
(0.21)\end{array}$ \\
\hline$\Delta I P L_{\mathrm{t}-4}$ & $\begin{array}{r}0.030 \\
(1.01)\end{array}$ & $\begin{array}{r}0.009 \\
(0.31)\end{array}$ & $\begin{array}{c}0.016 \\
(0.54)\end{array}$ & $\begin{array}{l}0.016 \\
(0.53)\end{array}$ \\
\hline$\Delta I P L_{\mathrm{t}-5}$ & $\begin{array}{l}0.005 \\
(0.21)\end{array}$ & $\begin{array}{l}0.008 \\
(0.36)\end{array}$ & $\begin{array}{l}0.016 \\
(0.75)\end{array}$ & $\begin{array}{l}0.017 \\
(0.76)\end{array}$ \\
\hline Adjusted $\mathrm{R}^{2}$ & .499 & .545 & .578 & .566 \\
\hline S.E. & 0.0223 & 0.0213 & 0.0205 & 0.0208 \\
\hline VECLM(1) & 6.36 & 5.67 & 5.17 & 5.03 \\
\hline VECLM(6) & 1.18 & 1.33 & 1.24 & 1.45 \\
\hline
\end{tabular}

Notes: ${ }^{+},{ }^{*}$ and ${ }^{* *}$ denote $90 \%, 95 \%$, and $99 \%$ significance levels, respectively. t-statistics in parentheses. Lag lengths of 5 yielded the strongest evidence for unique, significant vectors. The significance level of VECLM statistics accounts for size of the vector. 
Table 3: Biennial Models of Political Polarization in the U.S. Senate Using the Income Share of the Top 1\% to Measure Inequality

(1913-2009 Congresses spanning votes over 1913-2010)

Equilibrium Long-Run Relationship: Polar $S_{\mathrm{t}}=\lambda_{0}+\lambda_{1}$ Top $1 \% \mathrm{t}-1$

\begin{tabular}{|c|c|c|c|c|c|}
\hline & Model 1 & Model 2 & $\underline{\text { Model } 3}$ & Model 4 & Model 5 \\
\hline Constant & 0.3928 & 0.3992 & 0.3919 & 0.3056 & 0.3264 \\
\hline Top $1 \%{ }_{\mathrm{t}-1}$ & $\begin{array}{l}0.0111 \\
(1.49)\end{array}$ & $\begin{array}{l}0.0107 \\
(1.42)\end{array}$ & $\begin{array}{l}0.0112^{+} \\
(1.63)\end{array}$ & $\begin{array}{l}0.0173^{* *} \\
(3.23)\end{array}$ & $\begin{array}{l}0.0158^{*} \\
(2.54)\end{array}$ \\
\hline Eig. (1 vector) & 0.287 & 0.292 & 0.322 & 0.387 & 0.324 \\
\hline Eig. (2 vectors) & 0.033 & 0.034 & 0.022 & 0.005 & 0.002 \\
\hline Trace (1 vector) & $16.39^{*}$ & $16.70^{*}$ & $18.74^{*}$ & $21.72^{* *}$ & $17.32^{*}$ \\
\hline Trace (2 vectors) & 1.48 & 1.51 & 1.00 & 0.21 & 0.10 \\
\hline Max-Eig (1 vector) & $14.91^{*}$ & $15.19^{*}$ & $17.74^{*}$ & $21.52^{* *}$ & $17.22^{*}$ \\
\hline Max-Eig (2 vectors) & 1.48 & 1.51 & 1.00 & 0.21 & 0.10 \\
\hline Cointegration? & Yes $^{*}$ & Yes $^{*}$ & Yes $^{*}$ & $\mathrm{Yes}^{* *}$ & Yes $^{*}$ \\
\hline
\end{tabular}

Short-Run Models: $\Delta$ Polar $_{\mathrm{t}}=\alpha_{0}+\alpha_{1}(E C)_{\mathrm{t}-1}+\beta_{\mathrm{i}} \Delta\left(\right.$ Polar $S_{\mathrm{t}-\mathrm{i}}+\theta_{\mathrm{i}} \Delta(\operatorname{Top} 1 \%)_{\mathrm{t}-\mathrm{i}}+\delta Y_{\mathrm{t}}$

\begin{tabular}{|c|c|c|c|c|c|}
\hline $\begin{array}{l}\text { Sample } \\
\text { Variable }\end{array}$ & $\begin{array}{l}\text { 1923-2009 } \\
\text { Model 1 }\end{array}$ & $\begin{array}{l}\text { 1923-2009 } \\
\text { Model 2 }\end{array}$ & $\begin{array}{l}\text { 1923-2009 } \\
\text { Model } 3\end{array}$ & $\begin{array}{l}1923-2009 \\
\text { Model 4 } \\
\end{array}$ & $\begin{array}{l}1923-200 \\
\text { Model } 5 \\
\end{array}$ \\
\hline Constant & $\begin{array}{l}0.0002 \\
(0.04)\end{array}$ & $\begin{array}{l}-0.0062 \\
(-1.16)\end{array}$ & $\begin{array}{l}-0.0081 \\
(-1.60)\end{array}$ & $\begin{array}{l}0.0071 \\
(1.05)\end{array}$ & $\begin{array}{l}0.0089 \\
(1.23)\end{array}$ \\
\hline$E C_{\mathrm{t}-1}$ & $\begin{array}{l}-0.100 \\
(-1.53)\end{array}$ & $\begin{array}{l}-0.106^{+} \\
(-1.77)\end{array}$ & $\begin{array}{l}-0.129^{*} \\
(-2.26)\end{array}$ & $\begin{array}{l}-0.236^{* *} \\
(-3.60)\end{array}$ & $\begin{array}{l}-0.209^{* *} \\
(-3.04)\end{array}$ \\
\hline $\operatorname{Pres} 2 n d_{\mathrm{t}}$ & & $\begin{array}{l}0.040^{* *} \\
(2.66)\end{array}$ & $\begin{array}{l}0.035^{*} \\
(2.52)\end{array}$ & $\begin{array}{l}0.036^{* *} \\
(2.84)\end{array}$ & $\begin{array}{l}0.040^{* *} \\
(2.94)\end{array}$ \\
\hline Impeach $_{\mathrm{t}}$ & & & $\begin{array}{l}0.054^{*} \\
(2.42)\end{array}$ & $\begin{array}{l}0.052^{*} \\
(2.55)\end{array}$ & \\
\hline$N_{e w D e a l}$ & & & & $\begin{array}{l}-0.056^{* *} \\
(-3.03)\end{array}$ & $\begin{array}{l}-0.056^{* *} \\
(-2.85)\end{array}$ \\
\hline$\Delta$ Polar $_{\mathrm{t}-1}$ & $\begin{array}{l}0.256 \\
(1.54)\end{array}$ & $\begin{array}{l}0.195 \\
(1.27)\end{array}$ & $\begin{array}{l}0.187 \\
(1.30)\end{array}$ & $\begin{array}{l}0.224^{+} \\
(1.70)\end{array}$ & $\begin{array}{l}0.221 \\
(1.56)\end{array}$ \\
\hline$\Delta$ Polar $_{\mathrm{t}-2}$ & $\begin{array}{l}0.331^{+} \\
(1.96)\end{array}$ & $\begin{array}{l}0.350^{*} \\
(2.24)\end{array}$ & $\begin{array}{l}0.347^{*} \\
(2.38)\end{array}$ & $\begin{array}{l}0.286^{*} \\
(2.12)\end{array}$ & $\begin{array}{l}0.280^{+} \\
(1.91)\end{array}$ \\
\hline$\Delta$ Polar $_{\mathrm{t}-3}$ & $\begin{array}{l}0.021 \\
(0.12)\end{array}$ & $\begin{array}{l}0.208 \\
(1.17)\end{array}$ & $\begin{array}{l}0.262 \\
(1.55)\end{array}$ & $\begin{array}{l}0.220 \\
(1.41)\end{array}$ & $\begin{array}{l}0.156 \\
(0.93)\end{array}$ \\
\hline$\Delta$ Polar $S_{\mathrm{t}-4}$ & $\begin{array}{l}0.279 \\
(1.54)\end{array}$ & $\begin{array}{l}0.138 \\
(0.79)\end{array}$ & $\begin{array}{l}0.141 \\
(0.87)\end{array}$ & $\begin{array}{l}0.038 \\
(0.25)\end{array}$ & $\begin{array}{l}0.025 \\
(0.15)\end{array}$ \\
\hline
\end{tabular}




\begin{tabular}{|c|c|c|c|c|c|}
\hline$\Delta T o p 1 \%{ }_{\mathrm{t}-1}$ & $\begin{array}{c}0.034 \\
(0.92)\end{array}$ & $\begin{array}{c}0.003 \\
(0.94)\end{array}$ & $\begin{array}{l}0.003 \\
(0.91)\end{array}$ & $\begin{array}{l}-0.001 \\
(-0.18)\end{array}$ & $\begin{array}{l}0.000 \\
(0.04)\end{array}$ \\
\hline$\Delta T o p 1 \%{ }_{\mathrm{t}-2}$ & $\begin{array}{l}0.005 \\
(0.13)\end{array}$ & $\begin{array}{c}0.027 \\
(0.76)\end{array}$ & $\begin{array}{l}0.004 \\
(1.13)\end{array}$ & $\begin{array}{l}0.001 \\
(0.35)\end{array}$ & $\begin{array}{l}0.000 \\
(0.11)\end{array}$ \\
\hline$\Delta T o p 1 \%{ }_{\mathrm{t}-3}$ & $\begin{array}{l}-0.001 \\
(-0.20)\end{array}$ & $\begin{array}{l}-0.000 \\
(-0.02)\end{array}$ & $\begin{array}{l}-0.000 \\
(-0.07)\end{array}$ & $\begin{array}{l}-0.000 \\
(-0.13)\end{array}$ & $\begin{array}{l}-0.001 \\
(-0.03)\end{array}$ \\
\hline$\Delta T o p 1 \%{ }_{\mathrm{t}-4}$ & $\begin{array}{l}0.001 \\
(0.36)\end{array}$ & $\begin{array}{c}0.022 \\
(0.61)\end{array}$ & $\begin{array}{l}0.002 \\
(0.72)\end{array}$ & $\begin{array}{l}0.001 \\
(0.44)\end{array}$ & $\begin{array}{l}0.001 \\
(0.39) \\
\end{array}$ \\
\hline Adjusted $\mathrm{R}^{2}$ & .117 & .252 & .347 & .465 & .372 \\
\hline S.E. & 0.0393 & 0.0323 & 0.0273 & 0.0217 & 0.0287 \\
\hline VECLM(1) & 3.30 & 3.94 & 4.06 & 1.26 & 1.99 \\
\hline VECLM(6) & 1.16 & 1.49 & 1.72 & 1.12 & 1.16 \\
\hline
\end{tabular}

Notes: ${ }^{+},{ }^{*}$ and ${ }^{* *}$ denote $90 \%, 95 \%$, and $99 \%$ significance levels, respectively. t-statistics in parentheses. Lag lengths of 4 yielded the strongest evidence for unique, significant vectors. The significance level of VECLM statistics accounts for size of the vector. 
Table 4: Biennial Models of Political Polarization in the U.S. Senate Using the Preferable Inverted Pareto-Lorenz Measure of Inequality (1913-2009 Congresses spanning votes over 1913-2010)

Equilibrium Long-Run Relationship: $\operatorname{Polar}_{\mathrm{t}}=\lambda_{0}+\lambda_{1} I P L_{\mathrm{t}-1}$

\begin{tabular}{|c|c|c|c|c|c|}
\hline & Model 1 & Model 2 & Model 3 & Model 4 & Model 5 \\
\hline Constant & 0.1704 & 0.1600 & 0.1602 & $\overline{0.0807}$ & $\overline{0.0926}$ \\
\hline$I P L_{\mathrm{t}-1}$ & $\begin{array}{l}0.1802^{*} \\
(2.59)\end{array}$ & $\begin{array}{l}0.1852^{*} \\
(2.58)\end{array}$ & $\begin{array}{l}0.1851^{* *} \\
(2.76)\end{array}$ & $\begin{array}{l}0.2229^{* *} \\
(6.76)\end{array}$ & $\begin{array}{l}0.2172^{* *} \\
(5.60)\end{array}$ \\
\hline Eig. (1 vector) & 0.272 & 0.295 & 0.288 & 0.328 & 0.401 \\
\hline Eig. (2 vectors) & 0.012 & 0.020 & 0.004 & 0.001 & 0.000 \\
\hline Trace (1 vector) & $14.51^{+}$ & $15.89^{*}$ & $15.13^{+}$ & $17.09^{*}$ & $22.59^{* *}$ \\
\hline Trace (2 vectors) & 0.53 & 0.83 & 0.18 & 0.02 & 0.01 \\
\hline Max-Eig (1 vector) & $13.98^{+}$ & $15.02^{*}$ & $14.95^{*}$ & $17.07^{*}$ & $22.58^{* *}$ \\
\hline Max-Eig (2 vectors) & 0.53 & 0.87 & 0.18 & 0.02 & 0.01 \\
\hline Cointegration? & $\mathrm{Yes}^{+}$ & Yes* & $\mathrm{Yes}^{+, *}$ & Yes $^{*}$ & $\mathrm{Yes}^{* *}$ \\
\hline
\end{tabular}

Short-Run Models: $\Delta$ Polar $_{\mathrm{t}}=\alpha_{0}+\alpha_{1}(E C)_{\mathrm{t}-1}+\beta_{\mathrm{i}} \Delta\left(\operatorname{Polar}_{\mathrm{t}-\mathrm{i}}+\theta_{\mathrm{i}} \Delta(I P L)_{\mathrm{t}-\mathrm{i}}+\delta Y_{\mathrm{t}}\right.$

\begin{tabular}{|c|c|c|c|c|c|}
\hline $\begin{array}{l}\text { Sample } \\
\text { Variable }\end{array}$ & $\begin{array}{l}\text { 1923-2009 } \\
\text { Model 1 }\end{array}$ & $\begin{array}{l}\text { 1923-2009 } \\
\text { Model 2 }\end{array}$ & $\begin{array}{l}\text { 1923-2009 } \\
\text { Model } 3\end{array}$ & $\begin{array}{l}\text { 1923-2009 } \\
\text { Model } 4\end{array}$ & $\begin{array}{l}1923-2009 \\
\text { Model } 5 \\
\end{array}$ \\
\hline Constant & $\begin{array}{l}0.0016 \\
(0.00)\end{array}$ & $\begin{array}{l}-0.0043 \\
(-0.83)\end{array}$ & $\begin{array}{l}-0.0043 \\
(-1.26)\end{array}$ & $\begin{array}{l}0.0121^{*} \\
(2.05)\end{array}$ & $\begin{array}{l}0.0014^{*} \\
(2.11)\end{array}$ \\
\hline$E C_{\mathrm{t}-1}$ & $\begin{array}{l}-0.110^{+} \\
(-1.77)\end{array}$ & $\begin{array}{l}-0.094^{+} \\
(-1.62)\end{array}$ & $\begin{array}{l}-0.125^{*} \\
(-2.26)\end{array}$ & $\begin{array}{l}-0.302^{* *} \\
(-4.83)\end{array}$ & $\begin{array}{l}-0.269^{* *} \\
(-3.90)\end{array}$ \\
\hline $\operatorname{Pres} 2 n d_{\mathrm{t}}$ & & $\begin{array}{l}0.037^{*} \\
(2.50)\end{array}$ & $\begin{array}{l}0.031^{*} \\
(2.27)\end{array}$ & $\begin{array}{l}0.030^{* *} \\
(2.69)\end{array}$ & $\begin{array}{l}0.035^{* *} \\
(2.84)\end{array}$ \\
\hline Impeach $_{\mathrm{t}}$ & & & $\begin{array}{l}0.054^{*} \\
(2.54)\end{array}$ & $\begin{array}{l}0.053^{* *} \\
(3.09)\end{array}$ & \\
\hline NewDeal & & & & $\begin{array}{l}-0.069^{* *} \\
(-4.20)\end{array}$ & $\begin{array}{l}-0.069^{* *} \\
(-3.74)\end{array}$ \\
\hline$\Delta$ Polar $_{\mathrm{t}-1}$ & $\begin{array}{l}0.279^{+} \\
(1.77)\end{array}$ & $\begin{array}{r}0.234 \\
(1.58)\end{array}$ & $\begin{array}{l}0.226^{+} \\
(1.65)\end{array}$ & $\begin{array}{l}0.253^{*} \\
(2.25)\end{array}$ & $\begin{array}{l}0.253^{*} \\
(2.00)\end{array}$ \\
\hline$\Delta$ Polar $_{\mathrm{t}-2}$ & $\begin{array}{l}0.289^{+} \\
(1.83)\end{array}$ & $\begin{array}{l}0.312^{*} \\
(2.11)\end{array}$ & $\begin{array}{l}0.317^{*} \\
(2.32)\end{array}$ & $\begin{array}{l}0.255^{*} \\
(2.26)\end{array}$ & $\begin{array}{l}0.247^{+} \\
(1.95)\end{array}$ \\
\hline$\Delta$ Polar $_{\mathrm{t}-3}$ & $\begin{array}{l}0.047 \\
(0.28)\end{array}$ & $\begin{array}{l}0.195 \\
(1.15)\end{array}$ & $\begin{array}{l}0.246 \\
(1.56)\end{array}$ & $\begin{array}{l}0.221^{+} \\
(1.70)\end{array}$ & $\begin{array}{l}0.221 \\
(1.13)\end{array}$ \\
\hline$\Delta$ Polar $_{\mathrm{t}-4}$ & $\begin{array}{l}0.321^{+} \\
(1.85)\end{array}$ & $\begin{array}{l}0.178 \\
(1.04)\end{array}$ & $\begin{array}{l}0.193 \\
(1.22)\end{array}$ & $\begin{array}{l}0.085 \\
(0.64)\end{array}$ & $\begin{array}{l}0.067 \\
(0.45)\end{array}$ \\
\hline
\end{tabular}




$\begin{array}{llllll}\Delta I P L_{\mathrm{t}-1} & \begin{array}{l}0.073 \\ (1.33)\end{array} & \begin{array}{l}0.055 \\ (1.06)\end{array} & \begin{array}{l}0.062 \\ (1.30)\end{array} & \begin{array}{l}0.029 \\ (0.73)\end{array} & \begin{array}{c}0.023 \\ \end{array} \\ \Delta I P L_{\mathrm{t}-2} & -0.059 & -0.034 & -0.022 & -0.031 & -0.408 \\ & (-1.03) & (-0.63) & (-0.44) & (-0.77) & (-0.90) \\ & & & & & \\ \Delta I P L_{\mathrm{t}-3} & 0.073^{+} & 0.063^{+} & 0.057^{+} & 0.056^{*} & 0.062^{+} \\ & (1.83) & (1.69) & (1.63) & (2.01) & (1.96) \\ \Delta I P L_{\mathrm{t}-4} & & & & & \\ & -0.003 & -0.018 & -0.015 & -0.003 & -0.005 \\ \text { Adjusted R } & (-0.11) & (-0.60) & (-0.53) & (-0.15) & (-0.21) \\ \text { S.E. } & .207 & .312 & .409 & .608 & .503 \\ \text { VECLM(1) } & 0.0322 & 0.0297 & 0.0278 & 0.0226 & 0.0255 \\ \text { VECLM(6) } & 3.01 & 3.52 & 2.12 & 1.34 & 3.21 \\ & 2.55 & 2.46 & 2.93 & 2.33 & 2.53\end{array}$

Notes: ${ }^{+},{ }^{*}$ and ${ }^{* *}$ denote $90 \%, 95 \%$, and $99 \%$ significance levels, respectively. t-statistics in parentheses. Lag lengths of 4 yielded the strongest evidence for unique, significant vectors. The significance level of VECLM statistics accounts for size of the vector. 


\section{Table 5: Weak Exogeneity Tests}

\section{A. Testing Whether Polarization is Weakly Exogenous to the IPL Inequality Variable}

Estimate Short-Run Model: $\Delta(\text { Polar })_{\mathrm{t}}=\alpha_{0}+\alpha_{1}(E C)_{\mathrm{t}-1}+\beta_{\mathrm{i}} \Delta(\text { Polar })_{\mathrm{t}-\mathrm{i}}+\theta_{\mathrm{i}} \Delta(I P L)_{\mathrm{t}-\mathrm{i}}+\delta Y_{\mathrm{t}}$

Test whether $\alpha_{1}$ is equal to zero. For the House, rejected in Models 1 and 2, and resoundingly rejected in Models 3 and 4 which account for New Deal realignment effects. For the Senate, weakly rejected in Models 1 and 2, and resoundingly rejected in Models 3 and 4 which account for New Deal realignment effects.

Variable $\underline{\text { Model 1 }} \underline{\text { Model 2 }} \underline{\text { Model 3 }} \underline{\text { Model 4 }}$

\section{House Polarization}

$\begin{array}{lllll}E C_{\mathrm{t}-1} & -0.157^{*} & -0.160^{*} & -0.233^{* *} & -0.226^{* *} \\ & (-2.24) & (-2.41) & (-3.03) & (-2.83)\end{array}$

Senate Polarization

$\begin{array}{llllll}E C_{\mathrm{t}-1} & -0.110^{+} & -0.094^{+} & -0.125^{*} & -0.302^{* *} & -0.269^{* *} \\ & (-1.77) & (-1.62) & (-2.26) & (-4.83) & (-3.90)\end{array}$

\section{B. Testing Whether the IPL Inequality Variable is Weakly Exogenous to Polarization}

Estimate Short-Run Model: $\Delta(I P L)_{\mathrm{t}}=\alpha_{0}+\alpha_{1}(E C)_{\mathrm{t}-1}+\beta_{\mathrm{i}} \Delta(\text { Polar })_{\mathrm{t}-\mathrm{i}}+\theta \mathrm{i} \Delta(I P L)_{\mathrm{t}-\mathrm{i}}+\delta Y_{\mathrm{t}}$ Test whether $\alpha_{1}$ is equal to zero: for the House, rejected in Models 1-4. For the Senate, resoundingly rejected in Models 1 and 2, rejected in Model, and weakly rejected in models 4 and 5 which account for New Deal realignment effects.

Variable

Model 1

Model 2

$\underline{\text { Model } 3}$

$\underline{\text { Model } 4}$

Model 5

House Polarization

$E C_{\mathrm{t}-1}$

$-0.216^{*}$

$-0.207^{*}$

$-0.263^{*}$

$-0.265^{*}$

$(-2.54)$

$(-2.48)$

$(-2.28)$

$(-2.21)$

\section{Senate Polarization}

$E C_{\mathrm{t}-1}$

$-0.088^{* *}$

$-0.093^{* *}$

$(-2.81)$

$-0.088^{*}$

$-0.105^{+}$

$(-1.82)$

$-0.107^{+}$

$(-2.58)$

$(-1.96)$ 
